NBER WORKING PAPER SERIES

\title{
LONG-TERM CONSEQUENCES OF SECONDARY SCHOOL VOUCHERS: EVIDENCE FROM ADMINISTRATIVE RECORDS IN COLOMBIA
}

\author{
Joshua Angrist \\ Eric Bettinger \\ Michael Kremer \\ Working Paper 10713 \\ http://www.nber.org/papers/w10713 \\ NATIONAL BUREAU OF ECONOMIC RESEARCH \\ 1050 Massachusetts Avenue \\ Cambridge, MA 02138 \\ August 2004
}

Special thanks goes to Cristina Estrada, Claudia Gonzalez, Marcela Monsalvo, and Ana Gomez for research assistance. We are also grateful to Jorge Estrada for help interpreting Colombian ID numbers and to the staff at ICFES for providing data. We thank the National Institutes of Health, the World Bank, and Harvard's David Rockefeller Center for Latin American Studies for funding this research and Victor Chernozhukov for helpful discussions. The views expressed herein are those of the author(s) and not necessarily those of the National Bureau of Economic Research.

(C2004 by Joshua Angrist, Eric Bettinger, and Michael Kremer. All rights reserved. Short sections of text, not to exceed two paragraphs, may be quoted without explicit permission provided that full credit, including (C) notice, is given to the source. 
Long-Term Consequences of Secondary School Vouchers: Evidence from Administrative Records in Colombia

Joshua Angrist, Eric Bettinger, and Michael Kremer

NBER Working Paper No. 10713

August 2004

JEL No. I21, J13, I28

\begin{abstract}
Colombia's PACES program provided over 125,000 poor children with vouchers that covered half the cost of private secondary school. The vouchers were renewable annually conditional on adequate academic progress. Since many vouchers were assigned by lottery, program effects can reliably be assessed by comparing lottery winners and losers. Estimates using administrative records suggest the PACES program increased secondary school completion rates by $15-20$ percent. Correcting for the greater percentage of lottery winners taking college admissions tests, the program increased test scores by two-tenths of a standard deviation in the distribution of potential test scores. Boys, who have lower scores than girls in this population, show larger test score gains, especially in math.
\end{abstract}

Joshua Angrist

MIT

Department of Economics

50 Memorial Drive

Cambridge, MA 02142

and NBER

angrist@mit.edu

Eric Bettinger

Department of Economics

Case Western Reserve

Cleveland, $\mathrm{OH}$ 44106-7235

and NBER

bettinger@cwru.edu

Michael Kremer

Department of Economics

Littauer Center 207

Cambridge, MA 02138

and NBER

mkremer@fas.harvard.edu 


\section{Introduction}

Demand-side subsidies for education are increasingly common in developing countries. Chile and Colombia have both offered educational vouchers for private secondary schools, while Brazil, India, Israel, and Mexico have introduced student stipends that reward attendance and performance. Interest in demand-side subsidies in developing countries parallels interest in the United States, where publiclyfunded vouchers for private schools have been distributed in a number of cities. Along the same lines in higher education, merit scholarships for American college students have grown almost 50 percent in the past five years (College Board 2002).

Previous research on primary and secondary school vouchers typically focuses on the short-run effects of vouchers on test scores. The results so far suggest that vouchers benefit some groups of recipients, though the extent of test score gains is disputed. ${ }^{1}$ Missing from most studies of voucher effects is an assessment of impacts on longer-term outcomes - such as high school graduation rates - that are more clearly tied to economic success. Research on school vouchers naturally focuses on short-run outcomes because participants are young and many programs are recent. Moreover, long-run follow-up efforts are difficult and costly.

This paper examines the longer-run effects of Colombia's PACES program, one of the largest voucher initiatives ever implemented. ${ }^{2}$ Between 1991 and 1997, PACES awarded nearly 125,000 vouchers to low-income high school students. Since vouchers were renewable annually conditional on satisfactory academic progress as indicated by scheduled grade promotion, the program provided incentives for students to work harder as well as widening their schooling options. PACES vouchers may therefore have effects similar to merit-based college scholarships and test-based achievement awards (see, e.g. Angrist and Lavy 2003, Kremer, Miguel and Thornton, 2003, Dynarski 2003, Ashworth and Hardman 2001, Cornwell and Mustard 2002). In common with anti-dropout interventions in the US and

\footnotetext{
${ }^{1}$ See, e.g., Rouse (1998); Howell and Peterson (2002), and Krueger and Zhu (2003).

${ }^{2}$ PACES is an acronym for Programa de Amplicación de Cobertura de la Educación Secundaria.
} 
UK, however, the PACES program most likely provided achievement incentives for students at risk of repeating grades or dropping out of school, as opposed to those likely to excel in school.

A key feature of the PACES program for our purposes is that in Bogotá as well as a number of other large cities, the vouchers were awarded by lottery. The random assignment of vouchers facilitates a natural-experiment research design in which losers provide a comparison group for winners. In previous research (Angrist, Bettinger, Bloom, King, and Kremer, 2002), we used the PACES lotteries to estimate the impact of vouchers on years of school completed between $6^{\text {th }}$ and $8^{\text {th }}$ grade, grade repetition, test scores, and the probability of working. These results strongly suggest that voucher winners devoted more time to school and had higher test scores than they otherwise would have had. Most of the results in our earlier study are for students observed about three years after winning the vouchers but still three years before high school graduation. While these results support the notion that vouchers had a positive short-run effect on schooling and test scores, they do not tell us whether vouchers increased high school graduation rates and achievement at the end of school.

In an effort to close this gap, we turn here to an assessment that exploits administrative data from Colombia's centralized college entrance examinations, the ICFES test, taken by most high school graduates. ${ }^{3}$ The principal advantage of administrative records over survey methods is that there is no loss to follow-up and administrative data are much cheaper than surveys.

Since more lottery winners than losers took the ICFES exam, direct comparisons of test scores for winners and losers are subject to selection bias. We discuss a number of solutions to this selection problem. On balance, the results of our follow-up study point to lasting benefits for voucher winners, with substantially higher high school graduation rates and, after adjusting for selection bias, higher test scores among those who took the ICFES exam. Upper bounds on test-score effects are not as large at the upper end of the score distribution as at the lower end, though this could be because upper bounds are tighter higher in the distribution. In any case, the fact that the program increased test scores even fairly

\footnotetext{
${ }^{3}$ ICFES is an acronym for Colombia's college admissions testing service, the Instituto Colombiano Para El Fomento De La Educacion Superior.
} 
high in the score distribution suggests that the program increased learning not only by increasing incentives for students at risk of repeating grades, but also through other mechanisms, such as increasing school choice. We also find somewhat larger voucher effects for boys than for girls, especially in math. Because boys have lower test scores than girls, this implies the program reduced the male-female score gap.

The next section provides additional background on the PACES program and voucher lotteries. Section III presents estimates of the effect of PACES vouchers on high school graduation rates, as measured by ICFES registration rates. Section IV discusses the problem of selection bias in analyses of test scores and presents estimates of effects on scores using alternative approaches to the selection problem. Section V concludes the paper.

\section{Background}

\section{A. The PACES program}

The Colombian government established PACES in late 1991. The program targeted low-income families by offering vouchers to children in neighborhoods classified as falling into the two lowest socioeconomic strata (out of 6 possible strata). To qualify for a voucher, applicants must have been entering the Colombian secondary school cycle, which begins with grade 6, and have been aged 15 or under. Prior to applying, students must already have been admitted to a participating secondary school (i.e., one that would accept the voucher). Participating schools had to be located in participating towns, which included all of Colombia's largest cities. Many elite private schools opted out of the program, so just under half of private schools in the 10 largest cities accepted PACES vouchers in 1993.

PACES vouchers were worth about 190 US dollars in 1998. Our survey data show matriculation and monthly fees for private schools attended by voucher applicants in 1998 averaged about $\$ 340$, so most voucher recipients supplemented the voucher with private funds. By way of comparison, the average annual per-pupil public expenditure in Colombia's public secondary school system in 1995 was 
just over $\$ 350$ (DNP, 1999), and public school parents in our sample typically paid tuition or fees of roughly \$58. Per capita GNP in Colombia was then around \$2,280 (World Bank, 1999).

Participating schools tended to serve lower-income pupils, and to have lower tuition than nonparticipating private schools. Schools with a vocational curriculum were also over-represented among those in the program. Initially, vouchers could be used at both for-profit and non-profit schools, but after 1996, for-profit schools were excluded. In the peak years of 1994 and 1995 roughly 90,000 students used vouchers. Almost 40 percent of the approximately 3.1 million secondary school pupils in Colombia in 1995 attended private schools. In Bogotá, 58 percent of the 567,000 secondary school pupils attended private school.

Pupil-teacher ratios and facilities were similar in public and participating private schools, and many of the teachers in the private schools that were most likely to participate in the PACES program were moonlighting or retired public school teachers. Test score comparisons reported by King, Rawlings, Gutierrez, Pardo, and Torres (1997) show that achievement levels in participating private schools were close to levels in public schools, though significantly below achievement levels in non-participating private schools.

Vouchers were renewed automatically through eleventh grade, when Colombian high school ends, provided the recipient's academic performance warranted promotion to the next grade. In practice, approximately 86 percent of participating $6^{\text {th }}$ graders in our sample were promoted. It therefore seems likely that the incentive aspects of the PACES program were strongest for the weakest students, since these students were at greatest risk of failing a grade.

One of our identification strategies is based on the lotteries used to allocate vouchers when demand exceeded supply for a particular cohort and town. In this study we concentrate on one of the largest applicant cohorts, students in Bogotá who applied in 1994 to enter private school in $6^{\text {th }}$ grade in 1995. Assuming no grade repetition, students in this cohort would have been in $11^{\text {th }}$ grade, their last year 
of high school, in 2000. Any $11^{\text {th }}$ grader or high school graduate is eligible take the ICFES exam, which is required for admission to Colombian colleges and universities.

Our earlier results (Angrist et al, 2002) suggest that three years after entering the lottery, voucher winners were 16 percentage points more likely to be attending a private school. Fee payments for voucher winners were $\$ 52$ higher than for losers, suggesting that some winners may have used their vouchers to trade up to higher priced schools. Lottery winners and losers did not differ in enrollment rates, but winners had completed .12 additional years of school, partly because they were 6 percentage points less likely to have repeated a grade. But winners also appear to have learned more. Among a sub-sample of lottery applicants who agreed to take a standardized test, winners scored .2 standard deviations more than losers, the equivalent of a full grade level. However, the sample of test takers was small (only 283), and hence these differences were only marginally significant at conventional levels, and since only 60 percent of those asked to take the test did so, selection remained a potential concern.

\section{B. Data and Descriptive Statistics}

Table 1 reports descriptive statistics for the 1995 cohort of 4,044 voucher applicants. The demographic characteristics in the table were derived from the forms completed by applicants. About 59 percent of voucher applicants were awarded vouchers in the 1995 lottery. Applicants were almost 13 years old, on average, and about evenly split between boys and girls. Roughly 88 percent of applicants came from households with a telephone or access to a telephone.

We matched PACES applicants with records of whether they registered for the ICFES exam and their score on the exam using the Colombian national ID number, an identification number consisting of 11 digits, the first 6 of which show date of birth. (A detailed description of our matching procedure and test score database is given in the data appendix.) A final "check digit" in the ID number bears a mathematical relationship to the other digits. We used the embedded check digit and birth dates to 
determine whether ID numbers were valid. About 9.5 percent of applicants had invalid birth dates. ${ }^{4}$ Of the 3661 applicants with plausible birth dates, 97 percent reported valid ID numbers.

Voucher winners and losers have similar demographic characteristics, except possibly for a small age difference (columns 3-6 of Table 1). The age differences by voucher status appear to be driven by a few outliers, probably due to incorrectly coded ID numbers among losers. The age gap is smaller when the sample is limited to those with valid ID numbers, though still marginally significant. We therefore control for age when estimating voucher effects.

The first outcome of interest is a dummy for whether a PACES applicant registered for the ICFES test. In addition to signaling an interest in higher education, ICFES registration is an excellent proxy for high school graduation status since 90 percent of high school graduates take the test (The World Bank, 1993), while all of those tested must be in $11^{\text {th }}$ grade or have graduated high school (mostly the former).

One concern is the possibility that any initially incorrect ID numbers were more likely to have been corrected later among winners than losers and that this could lead to a spurious finding of higher match rates with ICFES registrations records among lottery winners. Differential correction rates could arise, for example, as a result of continued bureaucratic interaction between lottery winners and the authorities administering the PACES program.

In practice, however, there is little evidence of differential ID-number accuracy by voucher status in our data. Table 2 shows estimates of $\alpha_{0}$ in the regression model:

$$
\mathrm{v}_{\mathrm{i}}=\mathrm{X}_{\mathrm{i}}^{\prime} \beta_{0}+\alpha_{0} \mathrm{D}_{\mathrm{i}}+\epsilon_{\mathrm{i}}
$$

where $\mathrm{v}_{\mathrm{i}}$ is a dummy for the validity of applicant $i$ 's ID number, $\mathrm{D}_{\mathrm{i}}$ is an indicator for whether applicant $i$ won a voucher, and $\mathrm{X}_{\mathrm{i}}$ is a vector of controls for age and sex. Also reported are estimates with no covariates. $^{5}$

\footnotetext{
${ }^{4}$ Birth dates are considered valid when they imply applicants were aged 9-25.

${ }^{5}$ The standard errors reported in Table 2 and elsewhere are heteroscedasticity-consistent.
} 
Eighty-eight percent of all applicants had a valid ID number (Column 1 of Table 2)). Voucher winners were 1 percentage point less likely to have a valid ID, but this difference is not significantly different from zero. Restricting the sample to those with valid birth dates embedded in their ID numbers results in an even smaller voucher effect, with or without demographic controls. Results are also similar when estimated separately by sex. These results strongly suggest that voucher winners are not more likely to be matched solely because they have more accurately recorded ID numbers. ${ }^{6}$

\section{Effects on High School Graduation}

Estimates of voucher effects on high school graduation rates were constructed using an equation like (1), replacing the dependent variable with an indicator for ICFES registration. Students in the 1995 applicant cohort who were promoted on schedule should have registered to take the ICFES exam at one of two opportunities in the 2000 school year. Because some students may also have advanced or repeated grades, we searched for applicants in the population of students who registered for any exam offered in 2000 and 2001. If a student was found to have been tested more than once, we retained the first set of test scores. In addition, we experimented with more restrictive matching strategies using city of residence and students' names for validation. ${ }^{7}$

About 35 percent of PACES applicants were matched to ICFES records using ID numbers, a result that can be seen in the first row of Table 3. A stricter match definition that requires both ID numbers and city of residence to line up generates an overall match rate of 34 percent, while matching on ID numbers and the first 7 letters of students' last names produces a match rate of 33 percent. Finally, requiring both city and a 7-letter match generates a match rate of 32 percent.

\footnotetext{
${ }^{6} \mathrm{We}$ found some evidence of differential record-keeping in the first cohort of Bogotá applicants from 1992, before the lottery process was computerized. Because of this and other data problems, the 1992 applicant cohort was omitted from this study.

${ }^{7}$ An applicant's city was considered matched if he or she registered for the ICFES test in Bogotá. Of course, in practice, some Bogotá applicants may have been tested elsewhere. A few apparent matches from 1999 were included as well. See the data appendix for details.
} 
In models with no controls, vouchers are estimated to have raised ICFES registration rates about 7 percentage points. This can be seen in column 1 of Table 3. The voucher effect falls slightly to about 6 percentage points with demographic controls but remains significantly different from zero. The estimated effects are slightly larger for boys than for girls, and the base rate is lower for boys. Using city of residence to validate matches leads to slightly smaller treatment effects for girls and overall, but the change is not substantial. Validation by matching on names as well as ID numbers leads to treatment effects almost identical to those without validation, and validation using both city and name generates estimates similar to those using city only. On balance, the estimated effects of voucher status on ICFES registration are remarkably robust to changes in sample, specification, and the definition of a match. Thus, it seems fair to say that PACES vouchers increased the likelihood of ICFES registration, and probably high school graduation, by 5-7 percentage points, with no consistent pattern of differences by sex. This amounts to an increase of 15-20 percent in the probability students took the ICFES exam.

\section{Effects on College Entrance Exam Scores}

\section{A. The Selection Problem}

We turn here to an assessment of the effects of PACES vouchers on academic achievement as measured by ICFES test scores. The principal econometric challenge in an evaluation of effects on test scores arises from the fact that voucher winners were more likely than losers to take the test. Thus, the score distributions of winners and losers are no longer directly comparable. To see the likely consequences of differential test-taking rates for comparisons of scores among test-takers, let $\mathrm{y}_{1 \mathrm{i}}$ be the ICFES score student $i$ would obtain after winning the voucher and let $\mathrm{y}_{0 \mathrm{i}}$ denote the score student $i$ would

obtain otherwise. We assume that both of these potential outcomes are well-defined for all pupils, whether they actually took the test or not, and whether they won the lottery or not. The average causal effect of winning the voucher on the scores of all winners is $E\left[y_{1 i}-y_{0 i} \mid D_{i}=1\right]$. Of course, in practice, we 
only observe scores for those who were tested. Moreover, among tested pupils, we only observe $\mathrm{y}_{1 \mathrm{i}}$ for winners and $\mathrm{y}_{0 \mathrm{i}}$ for losers.

Using a notation paralleling the notation for potential test scores, let $\mathrm{T}_{1 \mathrm{i}}$ and $\mathrm{T}_{0 \mathrm{i}}$ denote potential test-taking status. That is, $\mathrm{T}_{1 \mathrm{i}}$ is a dummy for whether a student would have taken the ICFES after winning the lottery and $\mathrm{T}_{0 \mathrm{i}}$ is a dummy for whether a student would have taken the ICFES after losing the lottery. By virtue of the random assignment of $\mathrm{D}_{\mathrm{i}}$, the vector of all potential outcomes $\left\{\mathrm{y}_{1 \mathrm{i}}, \mathrm{y}_{0 \mathrm{i}}, \mathrm{T}_{1 \mathrm{i}}, \mathrm{T}_{0 \mathrm{i}}\right\}$ is jointly independent of $D_{i}$, though the elements of this vector are probably correlated with each other. Observed test-taking status, the dependent variable in the previous section, is linked to these potential outcomes by the equation:

$$
\mathrm{T}_{\mathrm{i}}=\mathrm{T}_{0 \mathrm{i}}+\left(\mathrm{T}_{1 \mathrm{i}}-\mathrm{T}_{0 \mathrm{i}}\right) \mathrm{D}_{\mathrm{i}}
$$

Similarly, the latent score variable (i.e., what we would observe if all students were tested) is

$$
\mathrm{y}_{\mathrm{i}}=\mathrm{y}_{0 \mathrm{i}}+\left(\mathrm{y}_{1 \mathrm{i}}-\mathrm{y}_{0 \mathrm{i}}\right) \mathrm{D}_{\mathrm{i}} .
$$

The observed win/loss contrast in test scores among those who were tested can be now written

$$
\begin{aligned}
\mathrm{E}\left[\mathrm{y}_{\mathrm{i}} \mid \mathrm{T}_{\mathrm{i}}=1, \mathrm{D}_{\mathrm{i}}=1\right]-\mathrm{E}\left[\mathrm{y}_{\mathrm{i}} \mid \mathrm{T}_{\mathrm{i}}=1, \mathrm{D}_{\mathrm{i}}=0\right] & =\mathrm{E}\left[\mathrm{y}_{1 \mathrm{i}} \mid \mathrm{T}_{1 \mathrm{i}}=1, \mathrm{D}_{\mathrm{i}}=1\right]-\mathrm{E}\left[\mathrm{y}_{0 \mathrm{i}} \mid \mathrm{T}_{0 \mathrm{i}}=1, \mathrm{D}_{\mathrm{i}}=0\right] \\
& =\mathrm{E}\left[\mathrm{y}_{1 \mathrm{i}} \mid \mathrm{T}_{1 \mathrm{i}}=1\right]-\mathrm{E}\left[\mathrm{y}_{0 \mathrm{i}} \mid \mathrm{T}_{0 \mathrm{i}}=1\right],
\end{aligned}
$$

where the second equality is because $D_{i}$ is randomly assigned. This contrast does not have a causal interpretation, since students with $\mathrm{T}_{1 \mathrm{i}}=1$ and $\mathrm{T}_{0 \mathrm{i}}=1$ are not drawn from the same population unless $\mathrm{D}_{\mathrm{i}}$ has no effect on the probability of being tested. In fact, we can expand this further to write

$$
\begin{aligned}
E\left[y_{i} \mid T_{i}=1, D_{i}=1\right]-E\left[y_{i} \mid T_{i}=1, D_{i}=0\right]= & E\left[y_{1 i}-y_{0 i} \mid T_{0 i}=1\right] \\
& +\left\{E\left[y_{1 i} \mid T_{1 i}=1\right]-E\left[y_{1 i} \mid T_{0 i}=1\right]\right\} .
\end{aligned}
$$

Equation (2) shows that the win/loss contrast among test-takers is equal to the average causal effect on those who would have been tested anyway, $\mathrm{E}\left[\mathrm{y}_{1 \mathrm{i}}-\mathrm{y}_{0 \mathrm{i}} \mid \mathrm{T}_{0 \mathrm{i}}=1\right]$, plus a term that captures the selection bias due to the fact that we are conditioning on ICFES registration status, itself an outcome that is correlated with potential test scores. 
The bias term in equation (2) is likely to be negative if PACES vouchers increased test scores. To illustrate this, suppose that $\mathrm{y}_{1 \mathrm{i}}=\mathrm{y}_{0 \mathrm{i}}+\alpha$, where $\alpha>0$, and that students choose to be tested if their potential scores exceeded a constant threshold, $\mu$. Then $\mathrm{T}_{\mathrm{ji}}=1\left[\mathrm{y}_{\mathrm{ji}}>\mu\right]$ for $\mathrm{j}=0,1$; and the selection bias is

$$
\mathrm{E}\left[\mathrm{y}_{1 \mathrm{i}} \mid \mathrm{y}_{1 \mathrm{i}}>\mu\right]-\mathrm{E}\left[\mathrm{y}_{1 \mathrm{i}} \mid \mathrm{y}_{1 \mathrm{i}}>\mu+\alpha\right]
$$

which is clearly negative. Of course, this example presumes that vouchers are never harmful. If vouchers were harmful, selection bias could (by the same argument) mask a negative treatment effect.

To provide an empirical basis for the claim that selection bias in the sample of ICFES takers is likely to be negative, we used test scores from our earlier random sample of Bogota students, the sample used by Angrist, et al (2002) to assess the effect of vouchers in learning. Although our sample of 259 tested students is somewhat more likely to have taken the ICFES test than the overall average test rate for the 1995 Bogota cohort (about 44\% versus 35\% overall), in contrast with the ICFES test, the likelihood of taking our test is the same for voucher winners and losers. Thus, the earlier sample of test takers is not be contaminated by self-selection bias of the sort affecting ICFES takers (though there is missing score data for other reasons).

A regression using stacked math and reading scores from the earlier testing sample generates a voucher effect of .186 , with effects measured in standard deviation units (and with a standard error adjusted for student clustering of .105). Limiting this sample to the roughly $44 \%$ of tested students who also took the ICFES generates a voucher effect of .044 (s.e.=.157). The pattern of substantial (and usually marginally significant) positive effects in the full sample and considerably smaller and insignificant treatment effects when this simple is limited to those who also took the ICFES test appears for all dependent variables and specifications. This finding illustrates the fact that conditioning on ICFES testing status almost certainly drives positive treatment effects towards zero. 


\section{B. Non-Parametric Bounds}

This section builds on the discussion above to derive a set of non-parametric bounds on quantilespecific program impacts on the distribution of test scores. Because selection bias is most likely negative when treatment effects are positive, selection-contaminated comparisons provide a lower bound on the likely impact of vouchers on achievement. Here, we also develop an upper bound by adapting a theoretical result from our earlier paper (Angrist, et al, 2002).

Suppose we are prepared to assume that winning the lottery was never harmful, i.e., that $\mathrm{y}_{1 \mathrm{i}} \geq \mathrm{y}_{0 \mathrm{i}}$ for all $i$. This seems reasonable since lottery winners were free to turn down their vouchers and attend public school if they felt continued voucher use was harmful. ${ }^{8}$ It also seems reasonable to assume $\mathrm{T}_{1 \mathrm{i}} \geq \mathrm{T}_{0 \mathrm{i}}$ since test-taking status is probably determined by, among other things, expected scores. Finally, it is useful to define a score variable that equals zero for those not tested:

$$
\mathrm{Y}_{\mathrm{ji}}=\mathrm{T}_{\mathrm{ji}} \mathrm{y}_{\mathrm{ji}} \text { for } \mathrm{j}=0,1 \text {. }
$$

Note that given our "never harmful" assumptions, we also have $\mathrm{Y}_{1 \mathrm{i}} \geq \mathrm{Y}_{0 \mathrm{i}}$ for all $\mathrm{i}$, and that

$$
\mathrm{E}\left[\mathrm{Y}_{1 \mathrm{i}}-\mathrm{Y}_{0 \mathrm{i}} \mid \mathrm{T}_{0 \mathrm{i}}=1\right]=\mathrm{E}\left[\mathrm{y}_{1 \mathrm{i}}-\mathrm{y}_{0 \mathrm{i}} \mid \mathrm{T}_{0 \mathrm{i}}=1\right] \text {. }
$$

The observed outcome, $\mathrm{Y}_{\mathrm{i}}$, is linked to potential outcomes by

$$
\mathrm{Y}_{\mathrm{i}}=\mathrm{Y}_{0 \mathrm{i}}+\left(\mathrm{Y}_{1 \mathrm{i}}-\mathrm{Y}_{0 \mathrm{i}}\right) \mathrm{D}_{\mathrm{i}}=\mathrm{T}_{0 \mathrm{i}} \mathrm{y}_{0 \mathrm{i}}+\left(\mathrm{T}_{1 \mathrm{i}} \mathrm{y}_{1 \mathrm{i}}-\mathrm{T}_{0 \mathrm{i}} \mathrm{Y}_{0 \mathrm{i}}\right) \mathrm{D}_{\mathrm{i}} \text {. }
$$

To simplify notation, drop subscripts for individuals and let $\mathrm{q}_{0}(\theta)$ be the $\theta$-quantile of the distribution of $Y_{0}$ and let $q_{1}(\theta)$ be the $\theta$-quantile of the distribution of $Y_{1}$. Assuming that students choose to be tested if their potential scores exceeded a constant threshold, the quantiles of $\mathrm{y}_{\mathrm{ji}}$ for test-takers are identified from the quantiles of $Y_{j i}$ for $\theta \geq \theta_{j}$ where $q_{j}\left(\theta_{j}\right)=0$.

For the development that follows, it's useful to define a rank-preserving restriction on the joint distribution of $\left(\mathrm{Y}_{0}, \mathrm{Y}_{1}\right)$ :

\footnotetext{
${ }^{8}$ This condition need not hold if some students who chose to use vouchers anticipated gains that did not materialize, with a subset ending up having been harmed by voucher use. In practice, however, the "never harmful" assumption is made more plausible by the fact that vouchers typically did not cover the entire cost of private school. This means that students using vouchers presumably expected gains large enough to outweigh the financial costs of attending private school, with a low risk of adverse academic effects.
} 
Definition. The random variable $\mathrm{Y}_{1}$ is said to be a $\theta$-quantile-preserving transformation ( $\left.\theta-\mathrm{QPT}\right)$ of the random variable $Y_{0}$ if $P\left(Y_{1} \geq q_{1}(\theta) \mid Y_{0} \geq q_{0}(\theta)\right)=1$.

Note that $\mathrm{Y}_{1}$ is a $\theta-\mathrm{QPT}$ of $\mathrm{Y}_{0}$ if the two potential outcomes are linking by a weakly increasing function, or if, for any two draws from the joint distributions of $Y_{1}$ and $Y_{0}$, the orderings of $Y_{1}$ and $Y_{0}$ are the same. The $\theta$-QPT concept extends this idea of rank-preservation to quantile-specific comparisons.

The following proposition establishes a set of quantile-specific bounds on average treatment effects in the presence of sample selection bias:

Proposition 1. Suppose that $\mathrm{y}_{1} \geq \mathrm{y}_{0}$ and $\mathrm{T}_{1} \geq \mathrm{T}_{0}$. Choose $\theta \geq \theta_{0}$ where $\mathrm{q}_{0}\left(\theta_{0}\right)=0$. Then

$$
\begin{aligned}
E\left[Y \mid D=1, Y>q_{1}(\theta)\right]-E\left[Y \mid D=0, Y>q_{0}(\theta)\right] \quad & \geq E\left[y_{1}-y_{0} \mid y_{0}>q_{0}(\theta), T_{0}=1\right] \\
& \geq E\left[Y \mid D=1, Y>q_{0}(\theta)\right]-E\left[Y \mid D=0, Y>q_{0}(\theta)\right] .
\end{aligned}
$$

Furthermore, if $Y_{1}$ is a $\theta$-quantile-preserving transformation of $Y_{0}$, then the left inequality is an equality.

Proof. $E\left[Y \mid D=j, Y>q_{j}(\theta)\right]=E\left[Y_{j} \mid Y_{j}>q_{j}(\theta)\right]$ by random assignment. Also,

$$
\begin{aligned}
E\left[Y_{1} \mid Y_{1}>q_{1}(\theta)\right]-E\left[Y_{0} \mid Y_{0}>q_{0}(\theta)\right] \quad & =E\left[Y_{1}-Y_{0} \mid Y_{0}>q_{0}(\theta)\right]+\left\{E\left[Y_{1} \mid Y_{1}>q_{1}(\theta)\right]-E\left[Y_{1} \mid Y_{0}>q_{0}(\theta)\right]\right\} \\
& \geq E\left[y_{1}-y_{0} \mid y_{0}>q_{0}(\theta), T_{0}=1\right]+b_{0} .
\end{aligned}
$$

If $\mathrm{Y}_{1}$ is a $\theta$-QPT of $\mathrm{Y}_{0}$ then $b_{0}=0$, so the second part is proved. Otherwise, we need to show that $b_{0} \geq 0$. Note that $b_{0}=\mathrm{E}\left[\mathrm{Y}_{1} 1\left(\mathrm{Y}_{1}>\mathrm{q}_{1}\right)-\mathrm{Y}_{1} 1\left(\mathrm{Y}_{0}>\mathrm{q}_{0}\right)\right] / \mathrm{P}\left(\mathrm{Y}_{0}>\mathrm{q}_{0}\right)$ since $\mathrm{P}\left(\mathrm{Y}_{1}>\mathrm{q}_{1}\right)=\mathrm{P}\left(\mathrm{Y}_{0}>\mathrm{q}_{0}\right)$, so, $b_{0} \geq \mathrm{E}\left[\mathrm{Y}_{1}\left(1\left(\mathrm{Y}_{1}>\mathrm{q}_{1}\right)-\mathrm{Y}_{1} 1\left(\mathrm{Y}_{0}>\mathrm{q}_{0}\right)\right)\right]$

$$
=E\left[Y_{1}\left(1\left(Y_{1}>q_{1}\right)-1\left(Y_{0}>q_{0}\right)\right)\right]=E\left[Y_{1}\left(1\left(Y_{1}>q_{1}, Y_{0}<q_{0}\right)-1\left(Y_{1}<q_{1}, Y_{0}>q_{0}\right)\right)\right]
$$

where the second equality above is a consequence of the facts that $1\left(Y_{1}>q_{1}\right)=1\left(Y_{1}>q_{1}, Y_{0}<q_{0}\right)+1\left(Y_{1}>q_{1}\right.$, $\left.\mathrm{Y}_{0}>\mathrm{q}_{0}\right)$ and $1\left(\mathrm{Y}_{0}>\mathrm{q}_{0}\right)=1\left(\mathrm{Y}_{1}<\mathrm{q}_{1}, \mathrm{Y}_{0}>\mathrm{q}_{0}\right)+1\left(\mathrm{Y}_{1}>\mathrm{q}_{1}, \mathrm{Y}_{0}>\mathrm{q}_{0}\right)$. Further simplifying, we have

$$
E\left[Y_{1}\left(1\left(Y_{1}>q_{1}, Y_{0}<q_{0}\right)-1\left(Y_{1}<q_{1}, Y_{0}>q_{0}\right)\right)\right]=E\left[Y_{1} \mid Y_{1}>q_{1}, Y_{0}<q_{0}\right] p_{1}-E\left[Y_{1} \mid Y_{1}<q_{1}, Y_{0}>q_{0}\right] p_{0},
$$


where $\mathrm{p}_{1} \geq \operatorname{Pr}\left[\mathrm{Y}_{1}>\mathrm{q}_{1}, \mathrm{Y}_{0}<\mathrm{q}_{0}\right]$ and $\mathrm{p}_{0} \geq \operatorname{Pr}\left[\mathrm{Y}_{1}<\mathrm{q}_{1}, \mathrm{Y}_{0}>\mathrm{q}_{0}\right]$. Clearly $\mathrm{E}\left[\mathrm{Y}_{1} \mid \mathrm{Y}_{1}>\mathrm{q}_{1}, \mathrm{Y}_{0}<\mathrm{q}_{0}\right] \geq \mathrm{E}\left[\mathrm{Y}_{1} \mid \mathrm{Y}_{1}<\mathrm{q}_{1}, \mathrm{Y}_{0}>\mathrm{q}_{0}\right]$. Also, $\mathrm{p}_{1}=\mathrm{p}_{0}$ because

$$
\mathrm{P}\left(\mathrm{Y}_{1}>\mathrm{q}_{1}\right)=\mathrm{p}_{1}+\operatorname{Pr}\left[\mathrm{Y}_{1}>\mathrm{q}_{1}, \mathrm{Y}_{0}>\mathrm{q}_{0}\right]=\theta=\operatorname{Pr}\left[\mathrm{Y}_{1}>\mathrm{q}_{1}, \mathrm{Y}_{0}>\mathrm{q}_{0}\right]+\mathrm{p}_{0}=\mathrm{P}\left(\mathrm{Y}_{0}>\mathrm{q}_{0}\right)
$$

This establishes the upper bound. The lower bound is a consequence of the fact that

$\mathrm{E}\left[\mathrm{Y} \mid \mathrm{D}=1, \mathrm{Y}>\mathrm{q}_{0}(\theta)\right]-\mathrm{E}\left[\mathrm{Y} \mid \mathrm{D}=0, \mathrm{Y}>\mathrm{q}_{0}(\theta)\right]=\mathrm{E}\left[\mathrm{Y}_{1}-\mathrm{Y}_{0} \mid \mathrm{Y}_{0}>\mathrm{q}_{0}(\theta)\right]+\left\{\mathrm{E}\left[\mathrm{Y}_{1} \mid \mathrm{Y}_{1}>\mathrm{q}_{0}(\theta)\right]-\mathrm{E}\left[\mathrm{Y}_{1} \mid \mathrm{Y}_{0}>\mathrm{q}_{0}(\theta)\right]\right\}$

and $\mathrm{E}\left[\mathrm{Y}_{1} \mid \mathrm{Y}_{0}>\mathrm{q}_{0}(\theta)\right]=\mathrm{E}\left[\mathrm{Y}_{1} \mid \mathrm{Y}_{1} \geq \mathrm{Y}_{0}>\mathrm{q}_{0}(\theta)\right] \geq \mathrm{E}\left[\mathrm{Y}_{1} \mid \mathrm{Y}_{1}>\mathrm{q}_{0}(\theta)\right]$

Note that we can choose a quantile, $\theta_{0}$, such that $\mathrm{q}_{0}\left(\theta_{0}\right)=0$, and then drop the lower $\theta_{0}$ percent of the $\mathrm{Y}_{1}$ distribution to obtain an upper bound on $\mathrm{E}\left[\mathrm{y}_{1}-\mathrm{y}_{0} \mid \mathrm{T}_{0}=1\right]$. At the same time, the unadjusted conditionalon-positive contrast in test scores provides a lower bound. Moreover, if $\mathrm{Y}_{1}$ and $\mathrm{Y}_{0}$ are linked by a $\theta-\mathrm{QPT}$, the upper bound provides an estimate of $E\left[\mathrm{y}_{1}-\mathrm{y}_{0} \mid \mathrm{T}_{0}=1\right] .{ }^{9}$ We can use this fact to estimate or bound average treatment effects at a number of points in the score distribution.

We can also use the proof of the proposition to get a sense of when the upper bound is likely to be tight. The bias of the upper bound is

$$
b_{0} \equiv \mathrm{E}\left[\mathrm{Y}_{1} \mid \mathrm{Y}_{1}>\mathrm{q}_{1}(\theta)\right]-\mathrm{E}\left[\mathrm{Y}_{1} \mid \mathrm{Y}_{0}>\mathrm{q}_{0}(\theta)\right] \text {, }
$$

which is equal to zero when $Y_{1}$ preserves the $\theta$-quantile of $Y_{0}$. Since some of the applicants induced to take the test by winning the lottery presumably scored above the minimum score achieved by applicants who took the test after losing the lottery, the bound is unlikely to be perfectly tight. However, since few of these "leap-frogging" applicants are likely to have scored in the upper quantiles of the distribution, the likelihood that the $\theta$-QPT assumption holds probably increases with $\theta$. We should therefore expect upper bounds estimated using the proposition to be tighter at the top of the distribution than the bottom.

\footnotetext{
${ }^{9}$ The latter result can also be understood as follows. Angrist (1997) shows that monotonicity in selection status $\left(\mathrm{T}_{1 \mathrm{i}} \geq \mathrm{T}_{0 \mathrm{i}}\right)$, combined with a constant-effects link between $\mathrm{y}_{1}$ and $\mathrm{y}_{0}$, implies that controlling the probability of sample selection eliminates selection bias. Symmetric truncation is equivalent to fixing the probability of sample selection. The proposition generalizes this result to models with a non-constant but still rank-preserving link between potential outcomes. Krueger and Whitmore (2001) used a similar idea to estimate $E\left[\mathrm{y}_{1}-\mathrm{y}_{0} \mid \mathrm{T}_{0}=1\right]$ in a study of class size. See also Lee (2002).
} 
Estimates of non-parametric bounds on treatment effects at different quantiles are reported in Tables $4 \mathrm{a}$ and $4 \mathrm{~b}$ for language and math scores, for $\theta_{0}$ such that $\mathrm{q}_{0}\left(\theta_{0}\right)=0$, and for $\theta=.75, .85$., and .95 . $^{10}$ The largest effects are at $\mathrm{q}_{0}\left(\theta_{0}\right)=0$, i.e., effects on all pupils who would have been tested even if they had not won the lottery. The lower bound for effects on language scores in this population is .68 (s.e.=.33), while the upper bound is 2.8 (s.e. $=.31$ ). For $\theta=.95$, the bounds fall to an insignificant .35 on the low end and still-significant 1.4 (s.e. $=.34)$ on the high end. The pattern of bounds by quantile is consistent with either a larger shift in scores for pupils with $\mathrm{Y}_{0}$ close to the low end of the test-takers' score distribution, or with a tightening of the upper bound at higher quantiles, or both.

The effects on math scores in the sample that includes boys and girls are generally somewhat smaller than those on language scores. In fact, lower bounds for the estimated effects on math scores are not significantly different from zero at every cutoff, while the lower bounds for language effects are at least marginally significant at the lower three cutoffs. Interestingly, most of the effects for boys are larger than the corresponding effects for girls, especially at the first two cutoffs and for the upper bounds. The difference in effects by sex is most marked for math scores.

A comparison of the entire distribution of test scores for winners and losers supports the notion that the voucher led to an increase in achievement by winners. Figures 1a and 1b, which plot kernel density estimates in the sample of all test takers, show slightly flattened and right-shifted distributions for winners. As with the comparisons of means, however, this contrast is contaminated by selection bias, in particular, the likely introduction of low-scorers into the sample of tested winners. Adjusting for sample selection bias as suggested by Proposition 1 leads to a clearer impression of a shift. This can be seen in Figures $2 \mathrm{a}$ and $2 \mathrm{~b}$, which plot score distributions after limiting the distribution of winners to the top 28 percent of the score distribution (including zeros). In other words, Figures $2 \mathrm{a}$ and $2 \mathrm{~b}$ plot scores conditional on $\mathrm{Y}_{0}>\mathrm{q}_{0}(.72)$, where $\mathrm{q}_{0}(.72)=0$, and $\mathrm{Y}_{1}>\mathrm{q}_{1}(.72)$. The adjusted figure shows a clearer rightward shift in the distribution for winners, especially in the middle of the density.

\footnotetext{
${ }^{10}$ These estimates are for the sample with valid ID and age as in Table 3; covariates include age and sex.
} 
The density plots and differences in average treatment effects reported for different quantiles in Tables $4 \mathrm{a}$ and $4 \mathrm{~b}$ suggest the PACES program had an impact on the distribution of test scores beyond a simple "location shift." To explore distribution effects further (and quantify the impression left by the figures), we estimated the impact of winning a voucher at different points in the cumulative distribution of test scores. In particular, we estimated voucher effects in equations analogous to equation (1), with the dependent variable given by $1\left[\mathrm{Y}_{\mathrm{i}}>c\right]$, where $c$ is a quantile in the score distribution among test takers. This procedure uses a sample where test scores for non-takers are coded as zero. Therefore, assuming that those not tested would have scored below $c$, the resulting estimates are unaffected by selection bias. ${ }^{11}$

Estimates of effects on the distribution of test scores, reported in Table 5, show the largest effects on the probability test scores exceeded the lowest decile in the score distribution (among test-takers). For example, the probit marginal effects of the impact of a voucher on the probability of crossing the first decile are .063 (s.e. $=.015)$ for the language score distribution and .068 (s.e.-.016) for the math score distribution. These estimates appear in columns 3 and 6 of Table 5. The corresponding estimates fall to a bit over .04 at the median, and then to around .025 at the $75^{\text {th }}$ percentile. It seems unlikely that many students at the $75^{\text {th }}$ percentile of the distribution of test scores among test takers were in danger of having to repeat a grade. The substantial impact of the program on the likelihood of scoring in the upper quartile among test takers therefore suggests the program operated through channels other than simply reducing the risk of grade repetition. Moreover, while the estimated distribution shifts at the upper decile in this specification are only .01 and .003 for language and math, the former effect is still significantly different from zero.

Another interesting finding that comes out of the distribution analysis, echoing the results in Tables $4 \mathrm{a}$ and $4 \mathrm{~b}$, is a reasonably clear pattern of larger voucher effects on the distribution of scores for

\footnotetext{
${ }^{11} \mathrm{An}$ alternative and perhaps more conventional procedure that captures effects on distribution while avoiding selection bias under the same assumptions is quantile regression (QR). In this case, however, quantile regression is made less attractive by the almost-discrete nature of the test scores. About 80 percent of the mass of the distribution of scores among takers falls into a range of 15 points or less. This near-discreteness causes QR estimates to behave poorly and invalidates standard asymptotic theory for QR since a regularity assumption for quantile regression is continuity of the dependent variable.
} 
boys than for girls. For example, the distribution shift at the median of the math score distribution is .059 (s.e.=.015) for boys and $.033($ s.e.=.017) for girls. Again, these are probit marginal effects. The differences in effects by sex are even larger in the corresponding linear probability model and when these effects are estimated in models without covariates.

\section{Parametric strategies}

The strategies discussed in the previous section rely on relatively weak functional-form and distributional assumptions at the cost of a possible reduction in statistical power and, for the first approach, the need to settle for bounds instead of point identification. Here we briefly explore a potentially more powerful parametric strategy that codes the latent scores of non-takers as falling below a particular value or quantile, then censors the score distribution at or above this value and uses Tobit to correct for censoring. A comparison of Tobit results using different censoring points provides a natural specification test for this procedure since, if correctly specified, results using different censoring points should be similar. A key drawback in this case is the need to assume normality of the uncensored latent score distribution. The quality of the normal approximation may be especially poor given the relatively discrete nature of the score data.

The idea behind this approach is spelled out in more detail below. We assume that the causal effect of interest could be estimated by regressing latent scores, $y_{i}$, on $D_{i}$ and covariates, $X_{i}$. That is, the regression of interest is

$$
\mathrm{y}_{\mathrm{i}}=\mathrm{X}_{\mathrm{i}}^{\prime} \beta+\alpha \mathrm{D}_{\mathrm{i}}+\eta_{\mathrm{i}}
$$

where $\eta_{\mathrm{i}}$ is a normally distributed error. Now, construct an artificially censored version of $\mathrm{Y}_{\mathrm{i}}$ using

$$
\mathrm{Y}_{\mathrm{i}}(\tau) \equiv 1\left[\mathrm{Y}_{\mathrm{i}}>\tau\right] \mathrm{Y}_{\mathrm{i}}
$$

for some positive threshold, $\tau$. Assuming any untested student would have scored at or below this threshold if they had been tested, the parameters in (4) can be consistently estimated by applying Tobit to $\mathrm{Y}_{\mathrm{i}}(\tau)$.This is not realistic for $\tau=0$ but it may be for, say, the $10^{\text {th }}$ percentile of the score distribution among 
test-takers. Finally, note that if Tobit using $\mathrm{Y}_{\mathrm{i}}\left(\tau_{0}\right)$ identifies $\alpha$, then Tobit using $\mathrm{Y}_{\mathrm{i}}\left(\tau_{1}\right)$ will also work for any threshold value $\tau_{1}$, such that $\tau_{1}>\tau_{0}$.

As a benchmark for this procedure, we again report estimates using the sample of test-takers, without adjusting for censoring. A simple comparison of winners' and losers' test scores in the sample of test-takers, presented in column 1 of Table 6 , shows winners scored about 0.7 points higher on the language exam, with similar though less precise effects in samples of boys and girls. ${ }^{12}$ The estimated effects for math scores are smaller though still positive. Censoring the score distribution at the first percentile among test-takers, including all students and without adjusting for censoring in the estimation, generates a voucher effect of $1.1($ s.e. $=.24)$ for language and $0.79($ s.e. $=.18)$ for math. These results are reported in column 2 .

Tobit estimates using data censored at the first and $10^{\text {th }}$ percentiles among test-takers suggest much larger effects than those that arise without correcting for selection bias. The Tobit estimates, reported in columns 3 and 4 of Table 6 , are on the order of 2-4 points for language and 2-3 points for math, in all cases significantly different from zero. Effects are at the lower end of this range, around 2 points, when the data are censored at the $10^{\text {th }}$ percentile. Consistent with some of the earlier results, Tobit estimates separately by sex lead to larger estimates for boys than for girls for both math and language scores.

Assuming the Tobit model applies to data censored at the first percentile, the Tobit coefficient estimates should be the same when estimated using data censored at the $10^{\text {th }}$. The decline in estimates moving column 3 to column 4 therefore suggests the first percentile is too low a threshold for the model to apply. On the other hand, Tobit estimates of $\alpha$ are remarkably stable when the distribution is artificially censored with a cutoff that removes the lower 10-80 percent of scores. This can be seen in Figures $3 \mathrm{a}$ and $3 \mathrm{~b}$, which plot the estimated Tobit coefficients and confidence bands for alternative censoring points. The estimated treatment effects are fairly stable at around 2 points, turning down

\footnotetext{
${ }^{12}$ The covariates and sample used here are the same as in Tables $3-5$.
} 
slightly when the lower 90 percent of scores among takers are censored. It should be noted, however, that the confidence intervals widen at this point. Moreover, normality may be a poorer approximation for the score distribution at the upper tail. On balance, the model summarized in (4) and (5) seems to provide reasonably coherent account of the voucher impact on latent scores. Effects in this range amount to a score gain of about $.2 \sigma$ where $\sigma$ is the standard deviation of the latent residual in equation (4). This is consistent with our earlier estimates of effects on achievement for a random sample of Bogotá $8^{\text {th }}$ graders in $1998 .^{13}$

\section{Summary and Conclusions}

This paper presents evidence on the impact of PACES vouchers on long-run outcomes for applicants to the Bogota voucher lottery. The PACES program allowed students to attend private schools, and was renewable annually, conditional on grade advancement. The random assignment of vouchers facilitates causal comparisons between those who did and not receive vouchers. Administrative data on college entrance exams allow us to estimate the impact of vouchers on high school graduation rates and scholastic achievement. Two potential empirical problems in a study of this sort are the possibility of higher false match rates for winners than losers and selection bias in comparisons of test scores among those who were tested. As it turns out, the quality of record-keeping appears to have been similar for winners and losers, so that false matches are probably not a problem. We used a variety of simple strategies to adjust for selection bias, with reasonably consistent results coming out of different methods.

The empirical results point to an increase in high school graduation rates of 5-7 percentage points, relative to a base rate of 25-30 percent. This finding is consistent with our earlier results showing a 10 percentage point increase in $8^{\text {th }}$ grade completion rates among voucher winners, as well as gains on a

\footnotetext{
${ }^{13}$ Effect sizes calculated using the distribution of the latent Tobit residual seem like an appropriate standard of comparison since, on one hand, the R-squared in the latent equation estimated here is likely to be small and, on the other, the research strategy used in our earlier study can be thought of as providing estimates of the standard deviation of latent scores since all applicants in the relevant sample were tested (i.e., whether or not they were likely to later register for ICFES).
} 
standardized test. The magnitude of the test score gains in our follow-up study turn partly on how selection bias is controlled. Tobit estimates with artificially censored data put the treatment effects at around 2 points, or roughly $.2 \sigma$ relative to the standard deviation of latent scores. Non-parametric bounds bracket this number, with a lower bound that is significantly different from zero in the full sample. Since the upper bound is exact under the assumption of a monotone shift, and the Tobit estimates satisfy a simple over-identification test, something close to the Tobit estimate of 2 points seems like a good summary estimate.

For the most part, bounds on average treatment effects at higher quantiles of the score distribution are smaller than those at the lower end. This may be because program effects were actually greatest at the bottom of the distribution, perhaps due to the incentive effects generated by PACES vouchers. However, it also seems likely that the upper bounds are tighter higher in the distribution for technical reasons having to do with the relationship between potential outcomes in the treated and non-treated states. In any case, the fact that lottery winners were substantially more likely to score in the top quartile on the national university entrance exam suggests that the program probably improved learning not only by increasing financial incentives, but also by expanding school choice. A final noteworthy result is that the effects we estimated for boys, who generally score lower in this population, tend to be somewhat larger than those estimated for girls. Thus, the voucher program acted to reduce male-female score differentials.

In conclusion, it is worth emphasizing that all of the estimation methods used here point towards a substantial gain in both high school graduation rates and achievement as a result of the voucher program. The size and persistence of this impact suggests PACES was a cost-effective intervention. Although the benefits of achievement gains per se are hard to quantify, there is a substantial economic return to high school graduation in Colombia. At a minimum this suggests demand-side financing efforts along the lines of the PACES program warrant further study. Another area for future work is a reconciliation between our results for Colombia, which consistently show large benefits to voucher recipients, and results for the U.S., which have been more mixed. One possibility is that gaps between the 
quality of public and private schools are greater in Colombia than in the U.S. Another is that PACES features not necessarily shared by other voucher programs, such as incentive effects and the option for those who would have gone to private school anyway to use vouchers to attend more expensive schools, played an important role in generating the gains documented here. 


\section{$\underline{\text { Data Appendix }}$}

\section{ICFES-matching Details}

The population to be matched consisted of 4,044 applicants from the 1995 PACES cohort in Bogotá. Matching was carried out by searching computer files in the ICFES offices in Bogotá. The search was implemented by our research assistants with assistance from ICFES staff members. ICFES tests are offered twice a year. We searched for matches among all test-takers in 1999, 2000, and 2001. 27 students with an exact ID match registered but never took the exam. We code this event as a match but assigned a score of zero. Another 44 had scores recorded from tests offered in 1999, before the ICFES was a re-designed and a new score scale introduced. We assigned these individuals the mean score for their age/sex cell among takers in 2000 and 2001. Results are similar when the 1999 matches are treated as non-matches.

\section{ICFES Subjects and Score Distribution}

The ICFES scores used here are from the redesigned scoring system introduced in March 2000. Our scores are for the Mathematics and Language components of the Common Core of Basic Competence (Nucleo Comun Competencias Basicas), which includes modules in Biology, Chemistry, Physics, Mathematics, Language, History, Geography, and a Foreign Language test chosen by the student. In addition to these required tests, students choose to be tested in up to four areas of specialization. The ICFES is given over a two-day period with two morning sessions and an afternoon session on the first day.

The Mathematics and Language components of the Common Core each take one hour and have

35 questions. Test scores are reported on a scale of $0-100$, with the score distribution highly concentrated in the 30-70 range. The distributions of Mathematics and Language scores for all those tested in Bogotá in March 2000 are shown in the appendix figures (for 6,868 examinees). 


\section{REFERENCES}

Angrist, Joshua D., "Conditional Independence in Sample Selection Models," Economics Letters 54, February 1997, 103-112.

Angrist, Joshua and Victor Lavy, "The Effect of High School Matriculation Awards: Evidence from Randomized Trials," NBER Working paper 9839, 2003.

Angrist, Joshua; Bettinger, Eric; Bloom, Erik; King, Elizabeth and Kremer, Michael, "Vouchers for Private Schooling in Colombia: Evidence from a Randomized Natural Experiment," American Economic Review 92, December 2002, 1535-1558.

Ashworth, K. and J. Hardman, "Education Maintenance Allowance: The First Year, A Qualitative Evaluation," Research Report RR257, Department for Education and Employment, 2001.

The College Board, Trends in Student Aid, Washington, D.C., 2002.

Cornwell, Christopher and David Mustard, "The Enrollment Effects of Merit-Based Financial Aid: Evidence from Georgia's HOPE Scholarship,” Journal of Labor Economics, 2002.

Dynarski, Susan, "The Consequences of Merit Aid.” NBER Working Paper 9400, 2003.

Howell, William G. and Paul E. Peterson (2002), The Education Gap: Vouchers and Urban Schools, Washington, DC: The Brookings Institution.

King, Elizabeth; Orazem, Peter and Wolgemuth, Darin, "Central Mandates and Local Incentives: The Colombia Education Voucher Program," Working Paper No. 6, Series on Impact Evaluation of Education Reforms, Development Economics Research Group, The World Bank, February 1998.

King, Elizabeth; Rawlings, Laura; Gutierrez, Marybell; Pardo, Carlos and Torres, Carlos, "Colombia's Targeted Education Voucher Program: Features, Coverage and Participation," Working Paper No. 3, Series on Impact Evaluation of Education Reforms, Development Economics Research Group, The World Bank, September, 1997.

Kremer, Michael, Edward Miguel and Rebecca Thornton, "Incentives to Learn," Harvard department of Economics, mimeo, 2003.

Krueger, Alan and Whitmore, Diane, "The Effect of Attending a Small Class in the Early Grades on College-Test Taking and Middle School Test Results: Evidence from Project STAR," Economic Journal, January 2001, 111(468).

Krueger, Alan and Pei Zhu, "Another Look at the New York City School Voucher Experiment," NBER Working Paper 9418, January 2003.

Lee, David, "Trimming for Bounds on Treatment Effects with Missing Outcomes," NBER Technical Working Paper 277, June 2002.

Rouse, Cecilia Elena, "Private School Vouchers and Student Achievement: An Evaluation of the Milwaukee Parental Choice Program," Quarterly Journal of Economics, May 1998, 13(2), 553602.

Sanchez, Fabio and Jairo Mendez, "Por que los ninos pobres no van a la escuela? (Determinantes de la asistencia escolar en Colombia)." mimeo, Departmento Nacional de Planeacion Republica de Colombia, 1995.

The World Bank, Research Department, Staff Appraisal Report: Colombia, Secondary Education Project, Human Resources Operations Division, Latin America and the Caribbean Region, Report No. 11834-CO, November 19, 1993.

The World Bank, World Development Report 1998/99, New York: Oxford University Press, 1999. 
Table 1. Characteristics of ICFES Matching Sample by Voucher Status

\begin{tabular}{|c|c|c|c|c|c|c|}
\hline & \multicolumn{2}{|c|}{ Means } & \multicolumn{4}{|c|}{$\begin{array}{l}\text { Difference by Voucher Status } \\
\text { (winners vs. losers) }\end{array}$} \\
\hline & $\begin{array}{c}\text { Full } \\
\text { Sample } \\
(1)\end{array}$ & $\begin{array}{l}\text { Sample W/ } \\
\text { Valid Age } \\
\text { (2) }\end{array}$ & $\begin{array}{c}\text { Full } \\
\text { Sample } \\
(3)\end{array}$ & $\begin{array}{l}\text { Sample w/ } \\
\text { Valid Ages } \\
\text { (4) }\end{array}$ & $\begin{array}{l}\text { Valid ID } \\
\text { and Age } \\
(5)\end{array}$ & $\begin{array}{c}\text { Valid ID and } \\
\text { Age and Has } \\
\text { Phone } \\
\text { (6) }\end{array}$ \\
\hline Won Voucher & .588 & .585 & & & & \\
\hline Valid ID & .876 & .967 & & & & \\
\hline $\begin{array}{l}\text { Age at Time of } \\
\text { Application }\end{array}$ & $\begin{array}{l}12.7 \\
(1.8)\end{array}$ & $\begin{array}{l}12.7 \\
(1.3)\end{array}$ & $\begin{array}{l}-.137 \\
(.064)\end{array}$ & $\begin{array}{l}-.086 \\
(.045)\end{array}$ & $\begin{array}{l}-.085 \\
(.044)\end{array}$ & $\begin{array}{l}-.091 \\
(.047)\end{array}$ \\
\hline Male & .487 & .493 & $\begin{array}{l}.004 \\
(.016)\end{array}$ & $\begin{array}{l}.011 \\
(.017)\end{array}$ & $\begin{array}{l}.012 \\
(.017)\end{array}$ & $\begin{array}{l}.008 \\
(.018)\end{array}$ \\
\hline Phone & .882 & .886 & $\begin{array}{l}.013 \\
(.010)\end{array}$ & $\begin{array}{l}.008 \\
(.011)\end{array}$ & $\begin{array}{l}.008 \\
(.011)\end{array}$ & --- \\
\hline $\mathrm{N}$ & 4044 & 3661 & 4044 & 3661 & 3542 & 3139 \\
\hline
\end{tabular}

Notes: Robust standard errors reported in parentheses. Regression estimates of differences by voucher status in column 4 are for sample with valid age data embedded in the National ID number. A valid age must be between 9 and 25. Column 5 limits the sample to those with a valid ID check digit and Column 6 further limits the sample to those with a phone. There are 1520 observations in Column 1 and 3664 in Column 2 for "Age at Time of Application." Other sample sizes are as shown. 
Table 2. Effect of Voucher Status on the Probability of Having a Valid ID

\begin{tabular}{|c|c|c|c|c|c|}
\hline & \multirow{2}{*}{$\begin{array}{c}\text { Full } \\
\text { Sample } \\
(1)\end{array}$} & \multicolumn{2}{|c|}{$\begin{array}{c}\text { Sample with Valid Age } \\
\text { Data }\end{array}$} & \multicolumn{2}{|c|}{$\begin{array}{c}\text { Sample with Valid Age } \\
\text { and Phone }\end{array}$} \\
\hline & & (2) & $(3)$ & (4) & (5) \\
\hline & & \multicolumn{2}{|c|}{ A. All Applicants } & \multirow{2}{*}{\multicolumn{2}{|c|}{.968}} \\
\hline $\begin{array}{l}\text { Dependent } \\
\text { Variable Mean }\end{array}$ & .876 & \multicolumn{2}{|c|}{.968} & & \\
\hline Voucher Winner & $\begin{array}{r}-.010 \\
(.010)\end{array}$ & $\begin{array}{l}.001 \\
(.006)\end{array}$ & $\begin{array}{l}-.0002 \\
(.0060)\end{array}$ & $\begin{array}{l}.001 \\
(.006)\end{array}$ & $\begin{array}{l}.0001 \\
(.0063)\end{array}$ \\
\hline Age & & & $\begin{array}{l}-.010 \\
(.002)\end{array}$ & & $\begin{array}{l}-.008 \\
(.002)\end{array}$ \\
\hline Phone & & & $\begin{array}{l}-.0003 \\
(.0092)\end{array}$ & & \\
\hline $\mathrm{N}$ & 4044 & 3661 & 3661 & 3244 & 3244 \\
\hline \multicolumn{6}{|c|}{ B. Female Applicants } \\
\hline $\begin{array}{l}\text { Dependent } \\
\text { Variable Mean }\end{array}$ & .862 & \multicolumn{2}{|c|}{.963} & \multicolumn{2}{|c|}{.971} \\
\hline Voucher Winner & $\begin{array}{l}-.023 \\
(.015)\end{array}$ & $\begin{array}{l}-.001 \\
(.009)\end{array}$ & $\begin{array}{l}-.002 \\
(.009)\end{array}$ & $\begin{array}{l}-.002 \\
(.010)\end{array}$ & $\begin{array}{l}-.003 \\
(.009)\end{array}$ \\
\hline Age & & & $\begin{array}{l}-.010 \\
(.003)\end{array}$ & & $\begin{array}{l}-.010 \\
(.003)\end{array}$ \\
\hline Phone & & & $\begin{array}{l}.003 \\
(.013)\end{array}$ & & \\
\hline $\mathrm{N}$ & 2076 & 1857 & 1857 & 1631 & 1631 \\
\hline \multicolumn{6}{|c|}{ C. Male Applicants } \\
\hline $\begin{array}{l}\text { Dependent } \\
\text { Variable Mean }\end{array}$ & .891 & \multicolumn{2}{|c|}{.971} & \multicolumn{2}{|c|}{.971} \\
\hline Voucher Winner & $\begin{array}{l}.004 \\
(.014)\end{array}$ & $\begin{array}{l}.003 \\
(.008)\end{array}$ & $\begin{array}{l}.002 \\
(.008)\end{array}$ & $\begin{array}{l}.004 \\
(.008)\end{array}$ & $\begin{array}{l}.003 \\
(.008)\end{array}$ \\
\hline Age & & & $\begin{array}{l}-.011 \\
(.003)\end{array}$ & & $\begin{array}{l}-.006 \\
(.003)\end{array}$ \\
\hline Phone & & & $\begin{array}{l}.001 \\
(.013)\end{array}$ & & \\
\hline $\mathrm{N}$ & 1968 & 1804 & 1804 & 1613 & 1613 \\
\hline
\end{tabular}


Table 3. Voucher Status and the Probability of ICFES Match

\begin{tabular}{|c|c|c|c|c|c|c|c|c|}
\hline & \multicolumn{2}{|c|}{ Exact ID Match } & \multicolumn{2}{|c|}{ ID and City Match } & \multicolumn{2}{|c|}{ ID and 7-letter Name Match } & \multicolumn{2}{|c|}{ ID, City, and 7-letter Match } \\
\hline & $(1)$ & $(2)$ & $(3)$ & $(4)$ & $(5)$ & (6) & $(7)$ & $(8)$ \\
\hline \multicolumn{9}{|c|}{ A. All Applicants $(\mathrm{N}=3542)$} \\
\hline Dependent Var. Mean & \multicolumn{2}{|c|}{.354} & \multicolumn{2}{|c|}{.339} & \multicolumn{2}{|c|}{.331} & \multicolumn{2}{|c|}{.318} \\
\hline \multirow{2}{*}{ Voucher Winner } & .072 & .059 & .069 & .056 & .072 & .059 & .068 & .056 \\
\hline & $(.016)$ & $(.015)$ & $(.016)$ & $(.014)$ & $(.016)$ & $(.014)$ & $(.016)$ & $(.014)$ \\
\hline \multirow[t]{2}{*}{ Male } & & -.052 & & -.053 & & -.043 & & -.045 \\
\hline & & $(.014)$ & & $(.014)$ & & $(.014)$ & & $(.014)$ \\
\hline \multirow[t]{2}{*}{ Age } & & -.160 & & -.156 & & -.153 & & -.149 \\
\hline & & $(.005)$ & & $(.005)$ & & $(.005)$ & & $(.005)$ \\
\hline \multicolumn{9}{|c|}{ B. Female Applicants $(\mathrm{N}=1789)$} \\
\hline Dependent Var. Mean & \multicolumn{2}{|c|}{.387} & \multicolumn{2}{|c|}{.372} & \multicolumn{2}{|c|}{.361} & \multicolumn{2}{|c|}{.348} \\
\hline \multirow[t]{2}{*}{ Voucher Winner } & .067 & .056 & .069 & .057 & .071 & .060 & .073 & .062 \\
\hline & $(.023)$ & $(.021)$ & $(.023)$ & $(.021)$ & $(.023)$ & $(.021)$ & $(.023)$ & $(.021)$ \\
\hline \multirow[t]{2}{*}{ Age } & & -.168 & & -.164 & & -.160 & & -.156 \\
\hline & & $(.006)$ & & $(.006)$ & & $(.006)$ & & $(.006)$ \\
\hline \multicolumn{9}{|c|}{ C. Male Applicants $(\mathrm{N}=1752)$} \\
\hline Dependent Var. Mean & \multicolumn{2}{|c|}{.320} & \multicolumn{2}{|c|}{.304} & \multicolumn{2}{|c|}{.302} & \multicolumn{2}{|c|}{.288} \\
\hline Voucher Winner & .079 & .063 & .071 & .055 & .074 & .059 & .065 & .050 \\
\hline & $(.022)$ & $(.020)$ & $(.022)$ & $(.020)$ & $(.022)$ & $(.020)$ & $(.022)$ & $(.020)$ \\
\hline Age & & -.153 & & -.148 & & -.146 & & -.141 \\
\hline & & $(.007)$ & & $(.007)$ & & $(.007)$ & & $(.006)$ \\
\hline
\end{tabular}

Notes. Robust standard errors are shown in parentheses. The sample includes all Bogotá 95 applicants with valid ID numbers and valid age data (i.e. ages 9 to 25 at application). The sample is the same as in Table 1, Column 5. 
Table 4a. Bounds on Voucher Effects on Language Scores, for Applicants Who Would Have Taken the ICFES Exam Anyway

\begin{tabular}{|c|c|c|c|c|c|c|}
\hline \multirow[b]{2}{*}{$\begin{array}{l}\text { Loser's Value at } \\
\text { Percentile }\end{array}$} & \multirow[b]{2}{*}{$\begin{array}{c}\text { Percentile of } \\
\text { Loser's Distribution }\end{array}$} & \multirow{2}{*}{$\begin{array}{c}\text { Loser's Avg } \\
\text { Score Above } \\
\text { Quantile } \\
\text { (1) }\end{array}$} & \multicolumn{2}{|c|}{ w/o Covs } & \multicolumn{2}{|c|}{$\mathrm{w} /$ Covs } \\
\hline & & & $\begin{array}{l}\text { Lower } \\
\text { Bound } \\
(2)\end{array}$ & $\begin{array}{c}\text { Upper } \\
\text { Bound } \\
(3)\end{array}$ & $\begin{array}{c}\text { Lower } \\
\text { Bound } \\
(4)\end{array}$ & $\begin{array}{c}\text { Upper } \\
\text { Bound } \\
(5)\end{array}$ \\
\hline \multicolumn{7}{|c|}{ A. All Applicants } \\
\hline 0 & $72^{\text {nd }}$ Percentile & $\begin{array}{l}46.9 \\
(5.5)\end{array}$ & $\begin{array}{c}.68 \\
(.33)\end{array}$ & $\begin{array}{l}2.81 \\
(.31)\end{array}$ & $\begin{array}{l}.70 \\
(.33)\end{array}$ & $\begin{array}{l}2.80 \\
(.31)\end{array}$ \\
\hline 41 & $75^{\text {th }}$ Percentile & $\begin{array}{l}48.7 \\
(3.9)\end{array}$ & $\begin{array}{l}.46 \\
(.26)\end{array}$ & $\begin{array}{l}2.47 \\
(.26)\end{array}$ & $\begin{array}{l}.49 \\
(.26)\end{array}$ & $\begin{array}{l}2.46 \\
(.26)\end{array}$ \\
\hline 47 & $85^{\text {th }}$ Percentile & $\begin{array}{l}51.2 \\
(3.0)\end{array}$ & $\begin{array}{c}.49 \\
(.27)\end{array}$ & $\begin{array}{l}2.39 \\
(.28)\end{array}$ & $\begin{array}{l}.50 \\
(.27)\end{array}$ & $\begin{array}{l}2.37 \\
(.28)\end{array}$ \\
\hline 52 & $95^{\text {th }}$ Percentile & $\begin{array}{l}55.6 \\
(1.7)\end{array}$ & $\begin{array}{l}.35 \\
(.31)\end{array}$ & $\begin{array}{l}1.38 \\
(.34)\end{array}$ & $\begin{array}{l}.36 \\
(.31)\end{array}$ & $\begin{array}{l}1.39 \\
(.34)\end{array}$ \\
\hline \multicolumn{7}{|c|}{ B. Female Applicants } \\
\hline 0 & $67^{\text {th }}$ Percentile & $\begin{array}{l}46.6 \\
(5.7)\end{array}$ & $\begin{array}{l}.65 \\
(.45)\end{array}$ & $\begin{array}{l}2.29 \\
(.42)\end{array}$ & $\begin{array}{l}.74 \\
(.45)\end{array}$ & $\begin{array}{l}2.33 \\
(.42)\end{array}$ \\
\hline 43 & $75^{\text {th }}$ Percentile & $\begin{array}{l}49.2 \\
(3.7)\end{array}$ & $\begin{array}{l}.46 \\
(.35)\end{array}$ & $\begin{array}{l}1.86 \\
(.35)\end{array}$ & $\begin{array}{l}.52 \\
(.35)\end{array}$ & $\begin{array}{l}1.87 \\
(.35)\end{array}$ \\
\hline 47 & $85^{\text {th }}$ Percentile & $\begin{array}{l}51.5 \\
(3.1)\end{array}$ & $\begin{array}{l}.31 \\
(.37)\end{array}$ & $\begin{array}{l}2.32 \\
(.40)\end{array}$ & $\begin{array}{l}.32 \\
(.37)\end{array}$ & $\begin{array}{l}2.31 \\
(.40)\end{array}$ \\
\hline 52 & $95^{\text {th }}$ Percentile & $\begin{array}{l}55.7 \\
(1.8)\end{array}$ & $\begin{array}{l}.11 \\
(.45)\end{array}$ & $\begin{array}{l}1.32 \\
(.52)\end{array}$ & $\begin{array}{l}.11 \\
(.45)\end{array}$ & $\begin{array}{l}1.34 \\
(.53)\end{array}$ \\
\hline \multicolumn{7}{|c|}{ C. Male Applicants } \\
\hline 0 & $74^{\text {th }}$ Percentile & $\begin{array}{l}47.3 \\
(5.3)\end{array}$ & $\begin{array}{l}.67 \\
(.48)\end{array}$ & $\begin{array}{l}3.19 \\
(.45)\end{array}$ & $\begin{array}{l}.66 \\
(.48)\end{array}$ & $\begin{array}{l}3.18 \\
(.45)\end{array}$ \\
\hline 36 & $75^{\text {th }}$ Percentile & $\begin{array}{l}47.9 \\
(4.6)\end{array}$ & $\begin{array}{l}.54 \\
(.44)\end{array}$ & $\begin{array}{l}2.61 \\
(.42)\end{array}$ & $\begin{array}{c}.54 \\
(.43)\end{array}$ & $\begin{array}{l}2.62 \\
(.41)\end{array}$ \\
\hline 47 & $85^{\text {th }}$ Percentile & $\begin{array}{l}51.6 \\
(2.9)\end{array}$ & $\begin{array}{l}.69 \\
(.39)\end{array}$ & $\begin{array}{l}1.36 \\
(.39)\end{array}$ & $\begin{array}{l}.69 \\
(.38)\end{array}$ & $\begin{array}{l}1.35 \\
(.38)\end{array}$ \\
\hline 51 & $95^{\text {th }}$ Percentile & $\begin{array}{l}54.6 \\
(2.1)\end{array}$ & $\begin{array}{l}.20 \\
(.44)\end{array}$ & $\begin{array}{l}2.33 \\
(.46)\end{array}$ & $\begin{array}{l}.27 \\
(.45)\end{array}$ & $\begin{array}{l}2.35 \\
(.47)\end{array}$ \\
\hline
\end{tabular}

Notes: The table reports bounds computed using the formulas in Proposition 1 in the text. Means and standard deviations are shown in column 1. Estimated bounds and standard errors are shown in columns 2-5. Columns 4-5 include controls for age and gender. 
Table 4b. Bounds on Voucher Effects on Math Scores, for Applicants Who Would Have Taken the ICFES Exam Anyway

\begin{tabular}{|c|c|c|c|c|c|c|}
\hline \multirow[b]{2}{*}{$\begin{array}{l}\text { Loser's Value at } \\
\text { Percentile }\end{array}$} & \multirow[b]{2}{*}{$\begin{array}{c}\text { Percentile of } \\
\text { Loser's Distribution }\end{array}$} & \multirow{2}{*}{$\begin{array}{c}\text { Loser's Avg } \\
\text { Score Above } \\
\text { Quantile } \\
\text { (1) }\end{array}$} & \multicolumn{2}{|c|}{ w/o Covs } & \multicolumn{2}{|c|}{ w/ Covs } \\
\hline & & & $\begin{array}{l}\text { Lower } \\
\text { Bound } \\
\text { (2) }\end{array}$ & $\begin{array}{c}\text { Upper } \\
\text { Bound } \\
\text { (3) }\end{array}$ & $\begin{array}{c}\text { Lower } \\
\text { Bound } \\
\text { (4) }\end{array}$ & $\begin{array}{c}\text { Upper } \\
\text { Bound } \\
\text { (5) }\end{array}$ \\
\hline \multicolumn{7}{|c|}{ A. All Applicants } \\
\hline 0 & $70^{\text {th }}$ Percentile & $\begin{array}{l}42.3 \\
(4.8)\end{array}$ & $\begin{array}{c}.40 \\
(.29)\end{array}$ & $\begin{array}{l}2.40 \\
(.27)\end{array}$ & $\begin{array}{l}.40 \\
(.29)\end{array}$ & $\begin{array}{l}2.41 \\
(.27)\end{array}$ \\
\hline 37 & $75^{\text {th }}$ Percentile & $\begin{array}{l}43.7 \\
(3.8)\end{array}$ & $\begin{array}{l}.35 \\
(.25)\end{array}$ & $\begin{array}{l}1.76 \\
(.25)\end{array}$ & $\begin{array}{l}.34 \\
(.25)\end{array}$ & $\begin{array}{l}1.76 \\
(.25)\end{array}$ \\
\hline 42 & $85^{\text {th }}$ Percentile & $\begin{array}{l}46.2 \\
(3.2)\end{array}$ & $\begin{array}{l}.24 \\
(.28)\end{array}$ & $\begin{array}{l}1.44 \\
(.28)\end{array}$ & $\begin{array}{l}.27 \\
(.28)\end{array}$ & $\begin{array}{l}1.48 \\
(.28)\end{array}$ \\
\hline 47 & $95^{\text {th }}$ Percentile & $\begin{array}{l}50.3 \\
(2.4)\end{array}$ & $\begin{array}{l}-.09 \\
(.39)\end{array}$ & $\begin{array}{l}1.85 \\
(.42)\end{array}$ & $\begin{array}{l}-.11 \\
(.39)\end{array}$ & $\begin{array}{l}1.80 \\
(.43)\end{array}$ \\
\hline \multicolumn{7}{|c|}{ B. Female Applicants } \\
\hline 0 & $68^{\text {th }}$ Percentile & $\begin{array}{l}42.3 \\
(4.7)\end{array}$ & $\begin{array}{l}.14 \\
(.38)\end{array}$ & $\begin{array}{l}1.63 \\
(.36)\end{array}$ & $\begin{array}{l}.18 \\
(.38)\end{array}$ & $\begin{array}{l}1.66 \\
(.36)\end{array}$ \\
\hline 39 & $75^{\text {th }}$ Percentile & $\begin{array}{l}44.3 \\
(3.3)\end{array}$ & $\begin{array}{l}.24 \\
(.32)\end{array}$ & $\begin{array}{l}1.08 \\
(.32)\end{array}$ & $\begin{array}{l}.27 \\
(.32)\end{array}$ & $\begin{array}{l}1.09 \\
(.32)\end{array}$ \\
\hline 42 & $85^{\text {th }}$ Percentile & $\begin{array}{l}46.2 \\
(2.8)\end{array}$ & $\begin{array}{l}.28 \\
. .34)\end{array}$ & $\begin{array}{l}1.53 \\
(.34)\end{array}$ & $\begin{array}{l}.32 \\
. .34)\end{array}$ & $\begin{array}{l}1.55 \\
(.34)\end{array}$ \\
\hline 47 & $95^{\text {th }}$ Percentile & $\begin{array}{l}49.9 \\
(1.6)\end{array}$ & $\begin{array}{l}.06 \\
(.40)\end{array}$ & $\begin{array}{l}2.19 \\
(.42)\end{array}$ & $\begin{array}{l}.06 \\
(.40)\end{array}$ & $\begin{array}{l}2.18 \\
(.42)\end{array}$ \\
\hline \multicolumn{7}{|c|}{ C. Male Applicants } \\
\hline 0 & $74^{\text {th }}$ Percentile & $\begin{array}{l}42.3 \\
(4.9)\end{array}$ & $\begin{array}{c}.70 \\
(.44)\end{array}$ & $\begin{array}{l}3.27 \\
(.42)\end{array}$ & $\begin{array}{l}.70 \\
(.44)\end{array}$ & $\begin{array}{l}3.28 \\
(.42)\end{array}$ \\
\hline 35 & $75^{\text {th }}$ Percentile & $\begin{array}{l}43.2 \\
(4.3)\end{array}$ & $\begin{array}{l}.66 \\
(.40)\end{array}$ & $\begin{array}{l}2.39 \\
(.40)\end{array}$ & $\begin{array}{l}.65 \\
(.40)\end{array}$ & $\begin{array}{l}2.39 \\
(.39)\end{array}$ \\
\hline 42 & $85^{\text {th }}$ Percentile & $\begin{array}{l}46.3 \\
(3.7)\end{array}$ & $\begin{array}{l}.27 \\
.(46)\end{array}$ & $\begin{array}{l}1.31 \\
(.47)\end{array}$ & $\begin{array}{l}.32 \\
(.46)\end{array}$ & $\begin{array}{l}1.37 \\
(.47)\end{array}$ \\
\hline 45 & $95^{\text {th }}$ Percentile & $\begin{array}{l}49.8 \\
(3.2) \\
\end{array}$ & $\begin{array}{l}-.60 \\
(.60) \\
\end{array}$ & $\begin{array}{l}2.45 \\
(.70) \\
\end{array}$ & $\begin{array}{l}-.61 \\
(.60) \\
\end{array}$ & $\begin{array}{l}2.44 \\
(.71) \\
\end{array}$ \\
\hline
\end{tabular}

Notes: The table reports bounds computed using the formulas in Proposition 1 in the text. Means and standard deviations are shown in column 1. Estimated bounds and standard errors are shown in columns 2-5. Columns 4-5 include controls for age and gender. 
Table 5. Effects on the Probability of Exceeding Test Score Percentiles

\begin{tabular}{|c|c|c|c|c|c|c|c|c|}
\hline & & & Lar & age Sco & & & Score & \\
\hline Test & & & OLS & OLS & Probit & & OLS & Probit \\
\hline Language & Math & Threshold & (1) & (2) & (3) & (4) & (5) & (6) \\
\hline & & & All Appl & $\operatorname{ats}(\mathrm{N}=$ & & & & \\
\hline 40 & 35 & $10^{\text {th }}$ & .069 & .057 & .063 & .073 & .061 & .068 \\
\hline & & Percentile & $(.016)$ & $(.014)$ & $(.015)$ & $(.016)$ & $(.014)$ & $(.016)$ \\
\hline 44 & 39 & $25^{\text {th }}$ & .055 & .045 & .047 & .062 & .052 & .054 \\
\hline & & Percentile & $(.014)$ & $(.013)$ & $(.014)$ & $(.015)$ & $(.014)$ & $(.014)$ \\
\hline 47 & 42 & $50^{\text {th }}$ & .050 & .043 & .041 & .051 & .044 & .044 \\
\hline & & Percentile & $(.012)$ & $(.012)$ & $(.011)$ & $(.012)$ & $(.012)$ & $(.011)$ \\
\hline 51 & 45 & $75^{\text {th }}$ & .033 & .030 & .025 & .034 & .031 & .027 \\
\hline & & Percentile & $(.009)$ & $(.008)$ & $(.007)$ & $(.009)$ & $(.009)$ & $(.008)$ \\
\hline 54 & 48 & $90^{\text {th }}$ & .015 & .013 & .010 & .005 & .003 & .003 \\
\hline & & Percentile & $(.006)$ & $(.006)$ & $(.004)$ & $(.006)$ & $(.006)$ & $(.005)$ \\
\hline & & & emale Ap & $\operatorname{cants}(\mathrm{N}$ & 788) & & & \\
\hline 40 & 35 & $10^{\text {th }}$ & .066 & .055 & .065 & .066 & .056 & .065 \\
\hline & & Percentile & $(.022)$ & $(.020)$ & $(.023)$ & $(.022)$ & $(.020)$ & $(.023)$ \\
\hline 43 & 39 & $25^{\text {th }}$ & .054 & .045 & .051 & .045 & .036 & .041 \\
\hline & & Percentile & $(.021)$ & $(.020)$ & $(.021)$ & $(.021)$ & $(.020)$ & $(.021)$ \\
\hline 47 & 42 & $50^{\text {th }}$ & .052 & .046 & .044 & .037 & .031 & .033 \\
\hline & & Percentile & $(.018)$ & $(.017)$ & $(.016)$ & $(.018)$ & $(.017)$ & $(.017)$ \\
\hline 51 & 45 & $75^{\text {th }}$ & .027 & .024 & .021 & .026 & .023 & .022 \\
\hline & & Percentile & $(.012)$ & $(.012)$ & $(.010)$ & $(.013)$ & $(.013)$ & $(.011)$ \\
\hline 54 & 48 & $90^{\text {th }}$ & .009 & .007 & .005 & -.001 & -.002 & -.001 \\
\hline & & Percentile & $(.008)$ & $(.008)$ & $(.006)$ & $(.008)$ & $(.008)$ & $(.006)$ \\
\hline & & & Male App & ants $(\mathrm{N}=$ & 753) & & & \\
\hline 41 & 37 & $10^{\text {th }}$ & .074 & .060 & .061 & .083 & .069 & .070 \\
\hline & & Percentile & $(.021)$ & $(.020)$ & $(.021)$ & $(.021)$ & $(.020)$ & $(.020)$ \\
\hline 44 & 40 & $25^{\text {th }}$ & .067 & .055 & .054 & .069 & .059 & .057 \\
\hline & & Percentile & $(.020)$ & $(.019)$ & $(.019)$ & $(.019)$ & $(.018)$ & $(.018)$ \\
\hline 48 & 42 & $50^{\text {th }}$ & .050 & .043 & .039 & .070 & .062 & .059 \\
\hline & & Percentile & $(.016)$ & $(.015)$ & $(.014)$ & $(.017)$ & $(.016)$ & $(.015)$ \\
\hline 51 & 45 & $75^{\text {th }}$ & .040 & .035 & .028 & .042 & .038 & .032 \\
\hline & & Percentile & $(.012)$ & $(.012)$ & $(.009)$ & $(.012)$ & $(.012)$ & $(.010)$ \\
\hline 55 & 48 & $90^{\text {th }}$ & .013 & .011 & .008 & .010 & .008 & .007 \\
\hline & & Percentile & $(.007)$ & $(.007)$ & $(.005)$ & $(.008)$ & $(.008)$ & $(.006)$ \\
\hline
\end{tabular}

Notes: The dependent variable indicates whether students exceeded various percentiles in the relevant score distribution for test-takers. Marginal effects are reported for probit estimates. Standard errors are reported in parentheses. 
Table 6. OLS and Tobit Estimates of the Effects of the Vouchers on ICFES Scores

\begin{tabular}{|c|c|c|c|c|}
\hline & $\begin{array}{c}\text { OLS with } \\
\text { score }>0 \\
\text { (1) }\end{array}$ & $\begin{array}{c}\text { OLS } \\
\text { censored at } \\
1 \% \\
(2)\end{array}$ & $\begin{array}{c}\text { Tobit } \\
\text { Censored at } \\
1 \% \\
(3)\end{array}$ & $\begin{array}{c}\text { Tobit } \\
\text { Censored at } \\
10 \% \\
(4)\end{array}$ \\
\hline \multicolumn{5}{|c|}{ A. Language Scores } \\
\hline \multicolumn{5}{|l|}{ Full Sample } \\
\hline Dep Var Mean & $\begin{array}{l}47.4 \\
(5.6)\end{array}$ & $\begin{array}{c}37.3 \\
(8.0)\end{array}$ & $\begin{array}{l}37.3 \\
(8.0)\end{array}$ & $\begin{array}{l}42.7 \\
(4.7)\end{array}$ \\
\hline Voucher Effect & $\begin{array}{c}.70 \\
(.33)\end{array}$ & $\begin{array}{l}1.14 \\
(.24)\end{array}$ & $\begin{array}{l}3.29 \\
(.70)\end{array}$ & $\begin{array}{l}2.06 \\
(.46)\end{array}$ \\
\hline \multicolumn{5}{|l|}{ Female Applicants } \\
\hline Dep Var Mean & $\begin{array}{l}47.0 \\
(5.7)\end{array}$ & $\begin{array}{l}37.6 \\
(8.1)\end{array}$ & $\begin{array}{l}37.6 \\
(8.1)\end{array}$ & $\begin{array}{l}42.8 \\
(4.7)\end{array}$ \\
\hline Voucher Effect & $\begin{array}{c}.74 \\
(.45)\end{array}$ & $\begin{array}{l}1.04 \\
(.34)\end{array}$ & $\begin{array}{l}2.88 \\
(.91)\end{array}$ & $\begin{array}{l}1.86 \\
(.59)\end{array}$ \\
\hline \multicolumn{5}{|l|}{ Male Applicants } \\
\hline Dep Var Mean & $\begin{array}{l}47.8 \\
(5.5)\end{array}$ & $\begin{array}{l}37.0 \\
(7.9)\end{array}$ & $\begin{array}{l}37.0 \\
(7.9)\end{array}$ & $\begin{array}{l}42.5 \\
(4.6)\end{array}$ \\
\hline Voucher Effect & $\begin{array}{c}.66 \\
(.48)\end{array}$ & $\begin{array}{l}1.25 \\
(.34)\end{array}$ & $\begin{array}{c}3.77 \\
(1.10)\end{array}$ & $\begin{array}{l}2.29 \\
(.71)\end{array}$ \\
\hline \multicolumn{5}{|c|}{ B. Math Scores } \\
\hline \multicolumn{5}{|l|}{ Full Sample } \\
\hline Dep Var Mean & $\begin{array}{l}42.5 \\
(4.9)\end{array}$ & $\begin{array}{l}35.7 \\
(5.8)\end{array}$ & $\begin{array}{l}35.7 \\
(5.8)\end{array}$ & $\begin{array}{l}37.6 \\
(4.6)\end{array}$ \\
\hline Voucher Effect & $\begin{array}{c}.40 \\
(.29)\end{array}$ & $\begin{array}{c}.79 \\
(.18)\end{array}$ & $\begin{array}{l}2.29 \\
(.51)\end{array}$ & $\begin{array}{l}1.98 \\
(.45)\end{array}$ \\
\hline \multicolumn{5}{|l|}{ Female Applicants } \\
\hline Dep Var Mean & $\begin{array}{l}42.3 \\
(4.8)\end{array}$ & $\begin{array}{l}35.9 \\
(5.8)\end{array}$ & $\begin{array}{l}35.9 \\
(5.8)\end{array}$ & $\begin{array}{l}37.8 \\
(4.6)\end{array}$ \\
\hline Voucher Effect & $\begin{array}{c}.18 \\
(.38)\end{array}$ & $\begin{array}{c}.62 \\
(.25)\end{array}$ & $\begin{array}{l}1.84 \\
(.66)\end{array}$ & $\begin{array}{l}1.60 \\
(.58)\end{array}$ \\
\hline \multicolumn{5}{|l|}{ Male Applicants } \\
\hline Dep Var Mean & $\begin{array}{l}42.8 \\
(5.0)\end{array}$ & $\begin{array}{l}34.8 \\
(6.1)\end{array}$ & $\begin{array}{l}34.8 \\
(6.1)\end{array}$ & $\begin{array}{l}38.9 \\
(3.8)\end{array}$ \\
\hline Voucher Effect & $\begin{array}{c}.70 \\
(.44)\end{array}$ & $\begin{array}{l}1.02 \\
(.27)\end{array}$ & $\begin{array}{l}3.03 \\
(.85)\end{array}$ & $\begin{array}{l}2.21 \\
(.62)\end{array}$ \\
\hline
\end{tabular}

Note: Robust standard errors are in parentheses. Censoring point is the indicated percentile of the test score distribution, conditional on taking the exam. Standard deviations are reported for the dependent variable means. Sample sizes in Column 1, Panel A are 1223 for the whole sample, 672 for females, and 551 for males. Sample sizes are similar in Column 1, Panel B with an additional male and female. The samples in the other columns are 3541 overall, 1788 women, and 1753 men. Covariates include age and gender. 
Figure 1a. Language Scores by Voucher Status (No Correction for Selection Bias) $\triangle \quad$ Voucher Winners
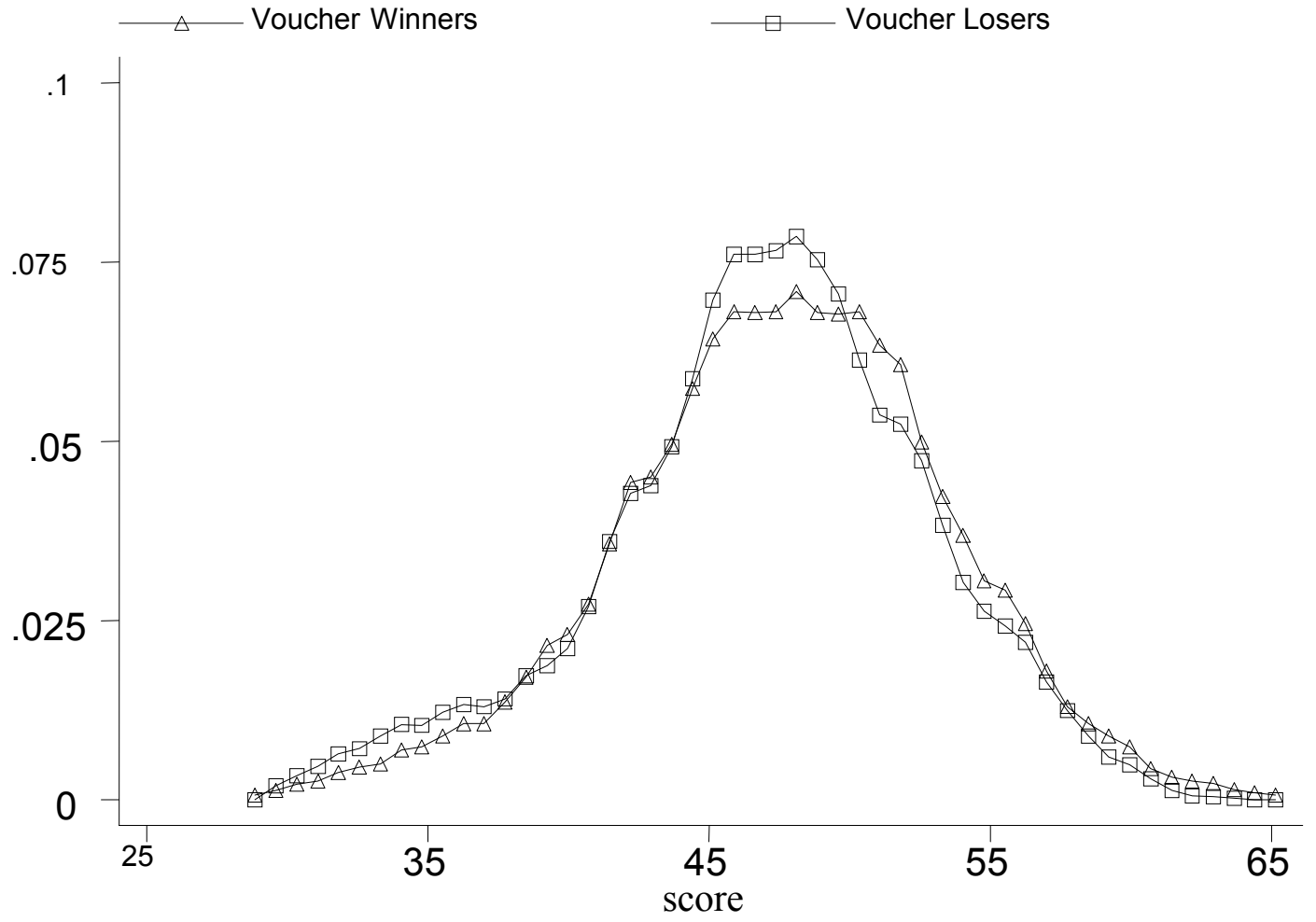

Figure 1b. Math Scores by Voucher Status (No Correction for Selection Bias)

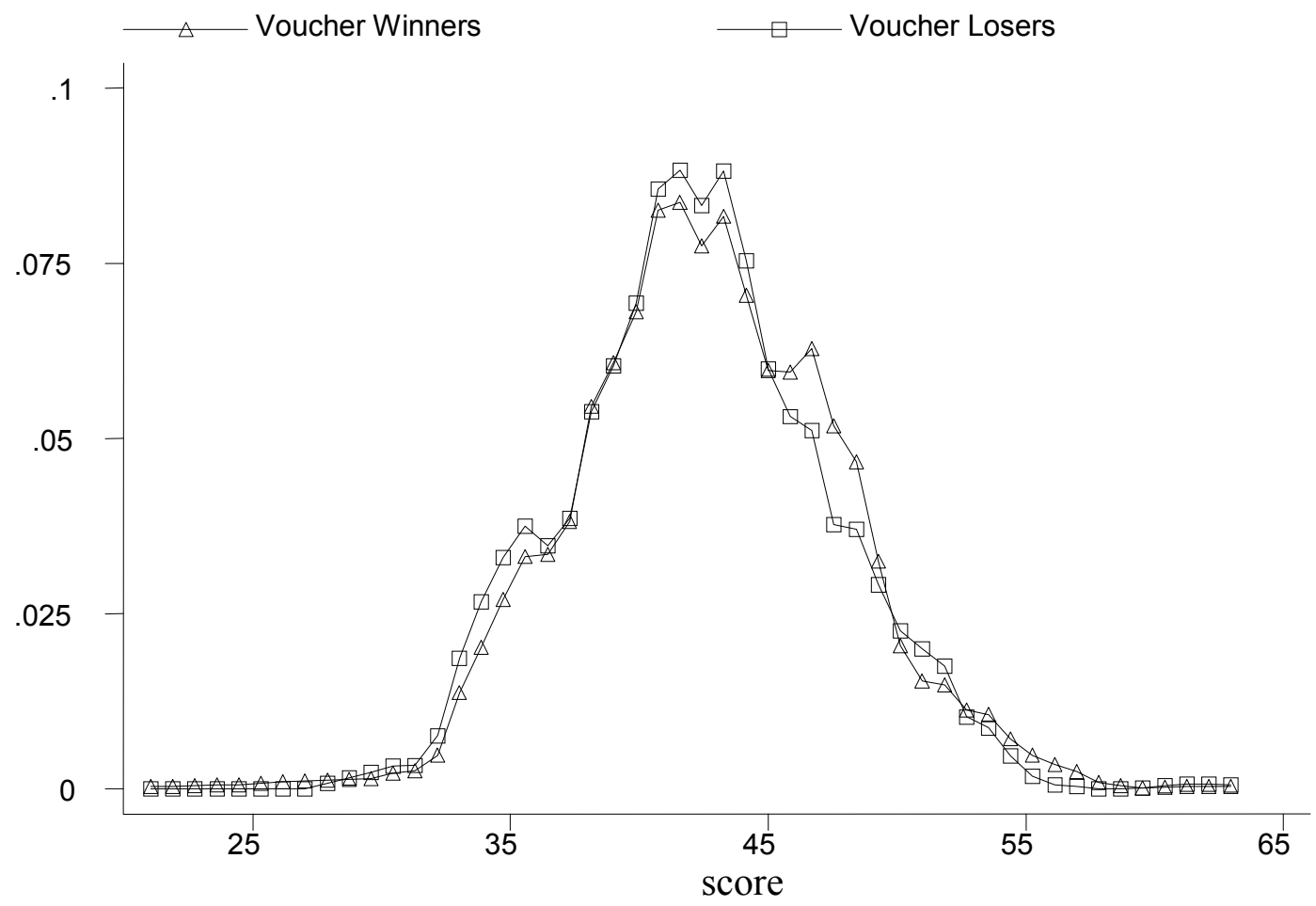


Figure 2a. Language Score Distribution by Voucher Status for Equal Proportions of Winners and Losers

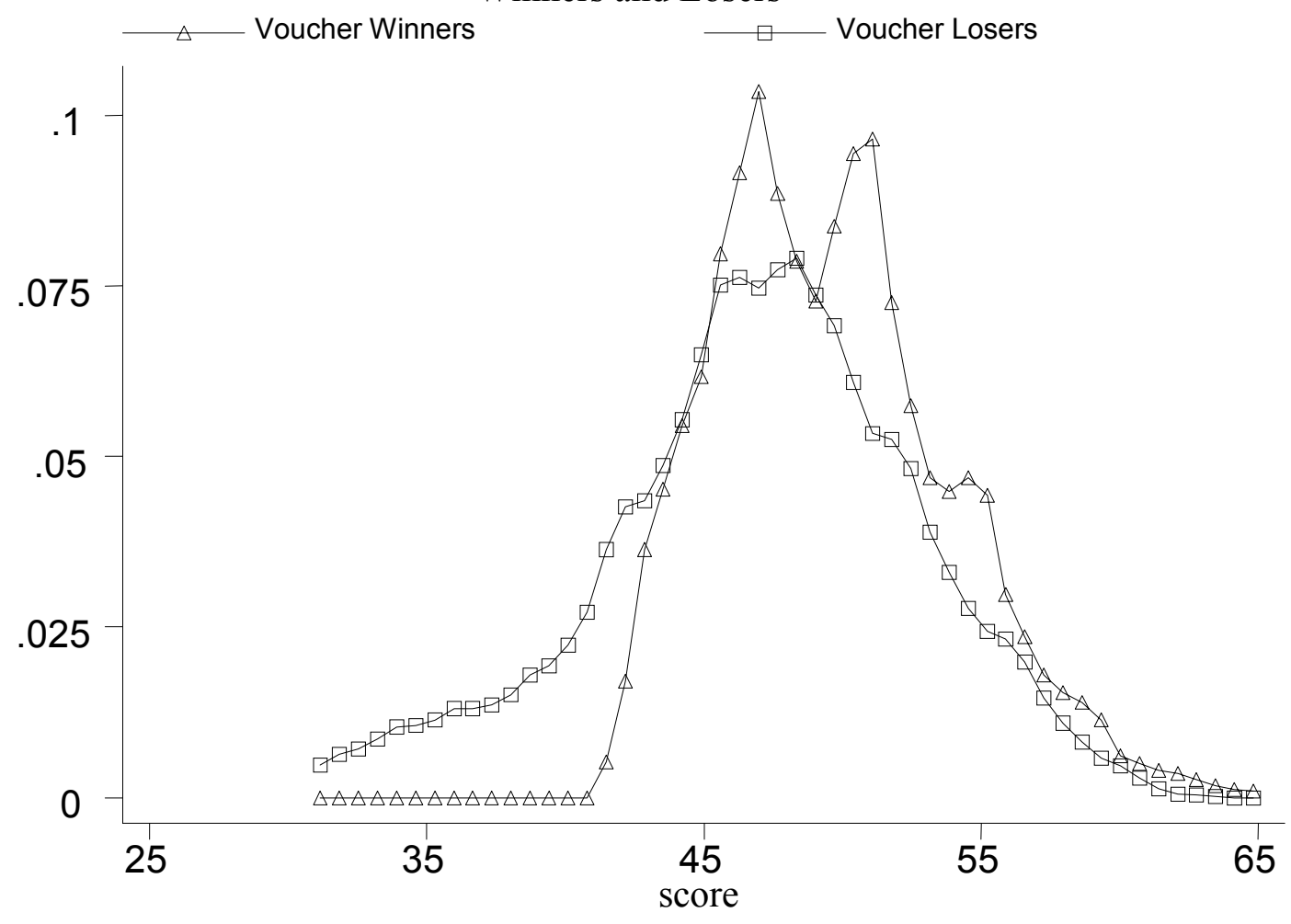

Figure 2b. Math Score Distribution by Voucher Status for Equal Proportions of Winners and Losers

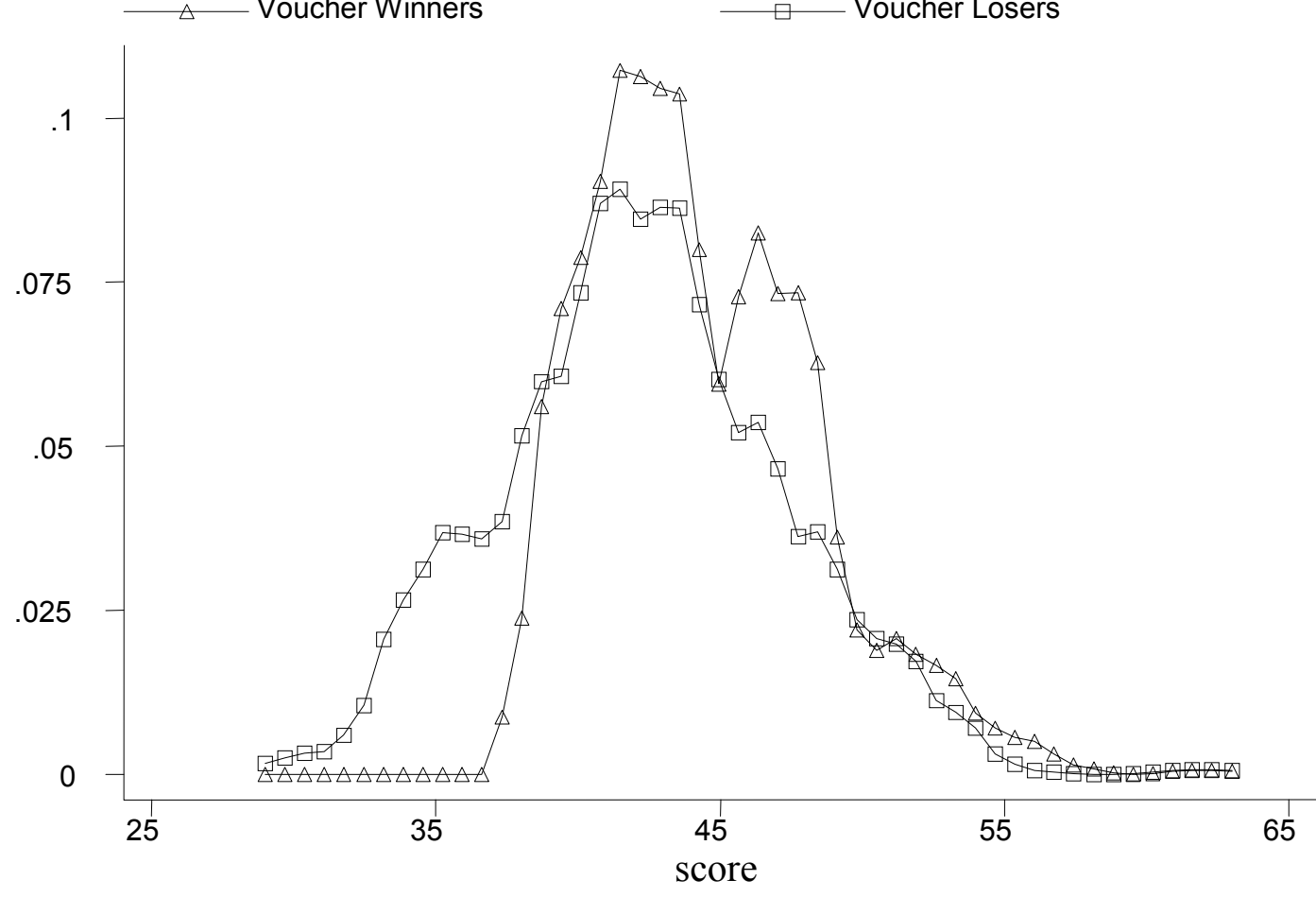


Figure 3a. Tobit Coefficients by Censoring Percentile in Language Score Distribution

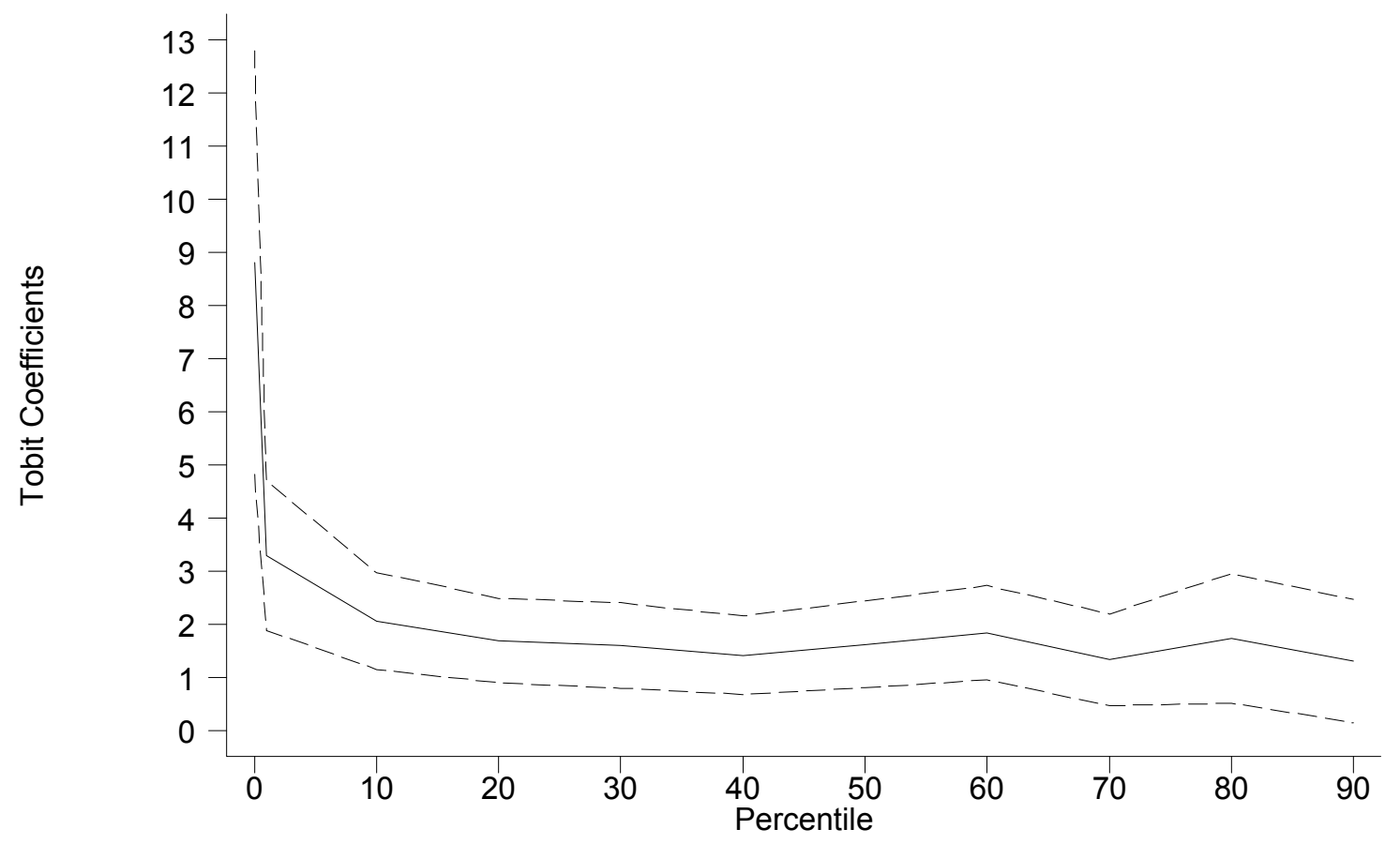

Figure 3b. Tobit Coefficients by Censoring Percentile in Math Score Distribution

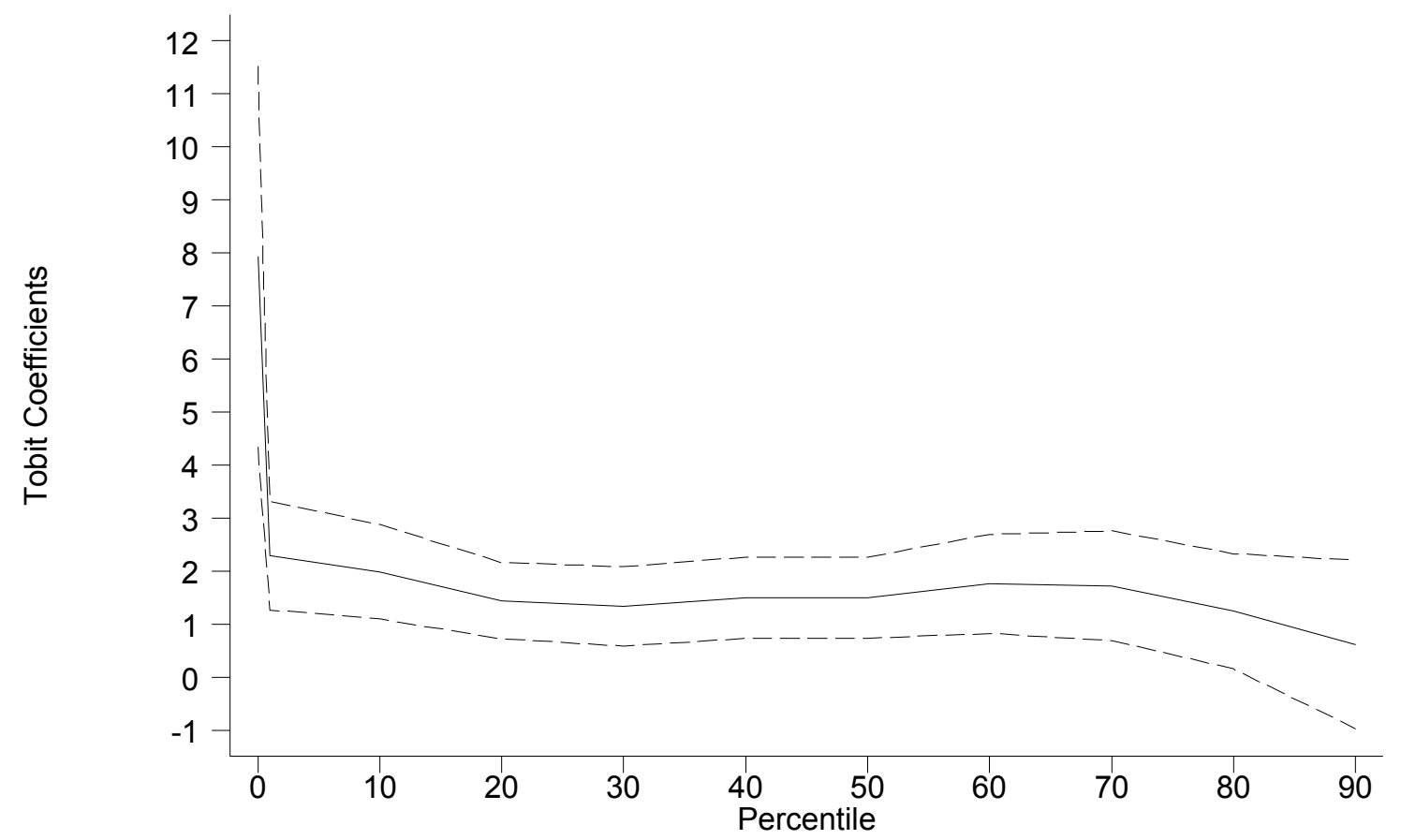


Appendix Figure Ia. Distribution of Language Scores in Bogota versus PACES Sample

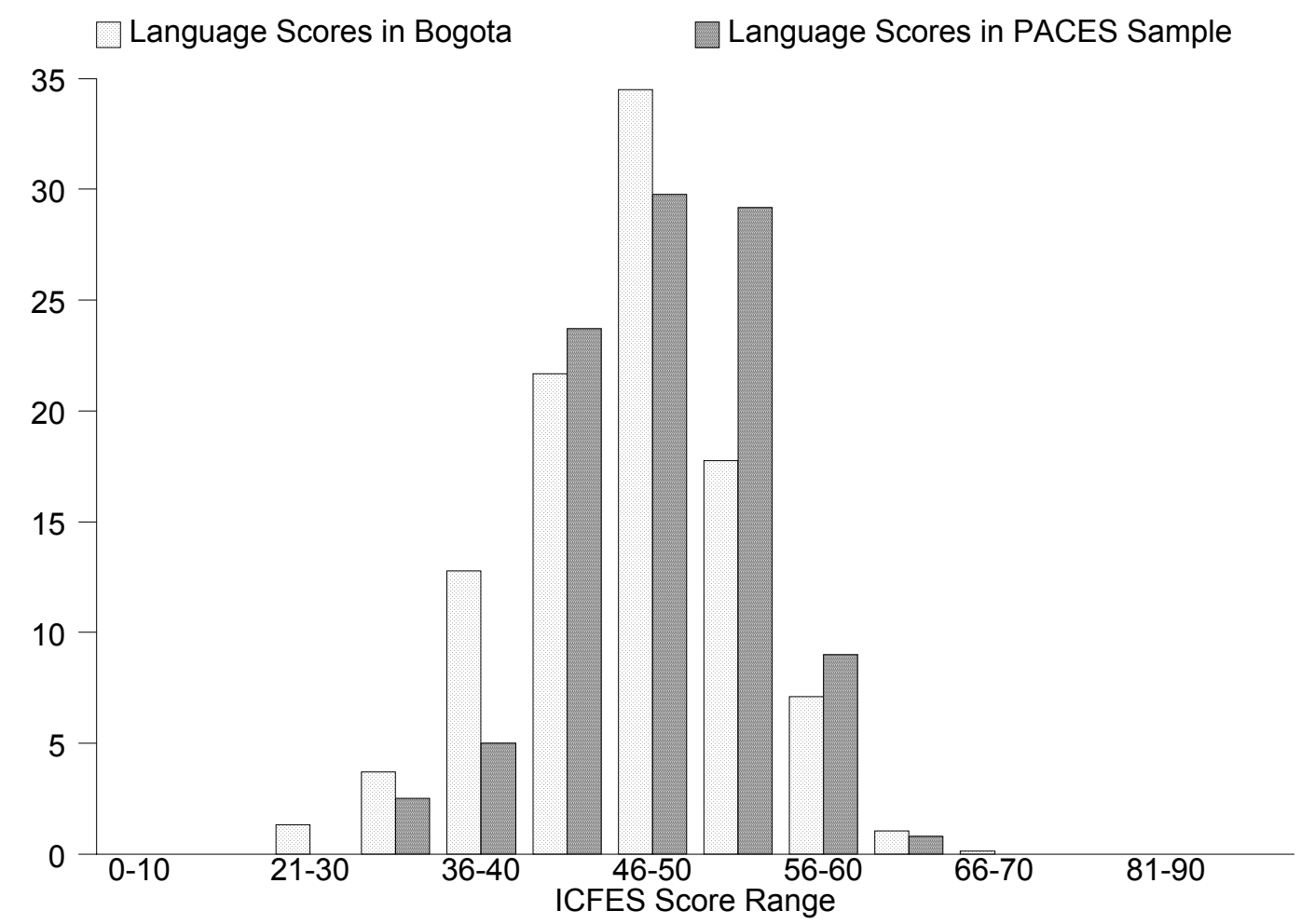

Appendix Figure Ib. Distribution of Math Scores in Bogota versus PACES Sample

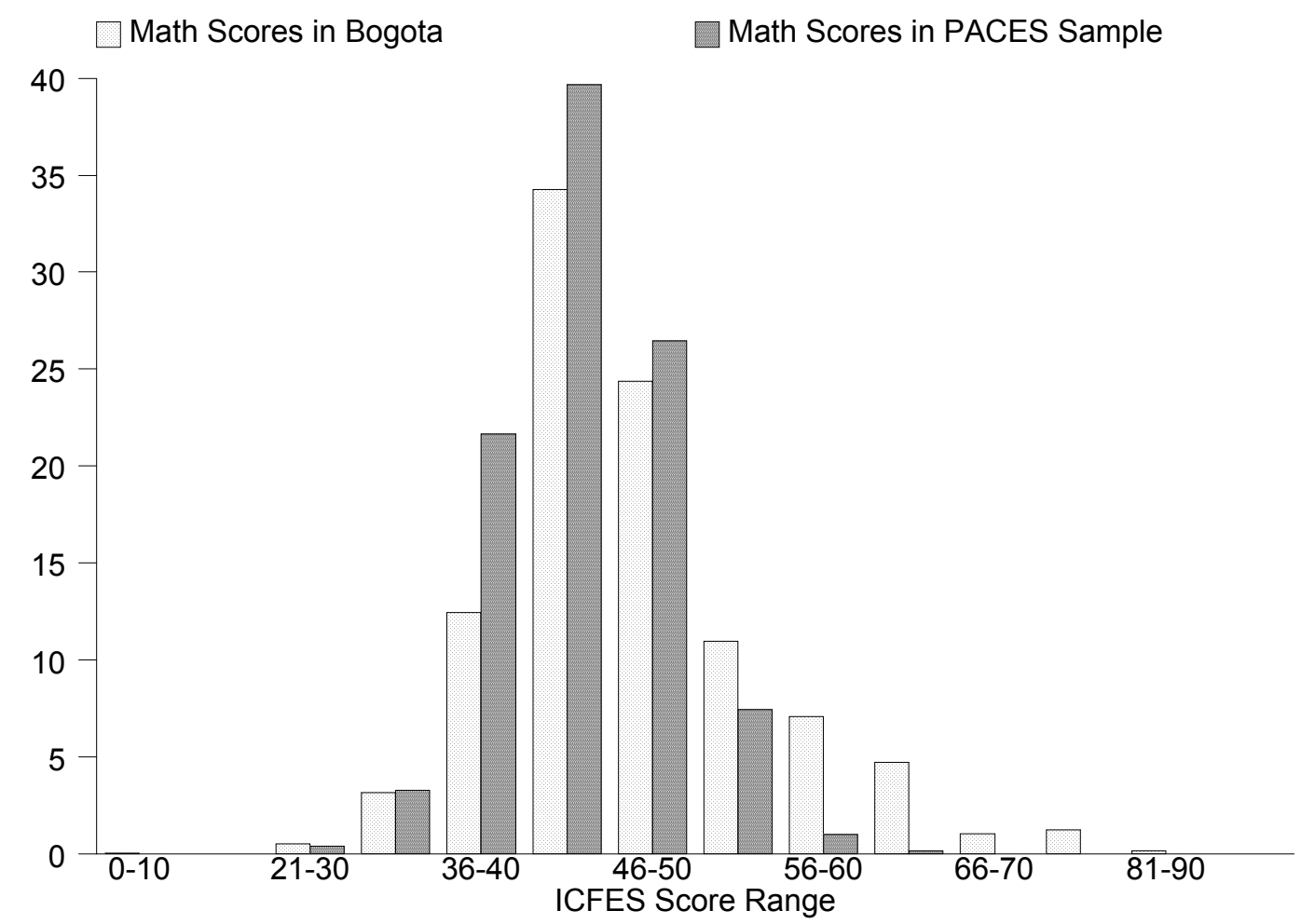

